Chromosome Studies in Sminthillus from Cuba and Eleutherodactylus from Cuba and Puerto Rico (Anura: Leptodactylidae)

James $P$. Bogart

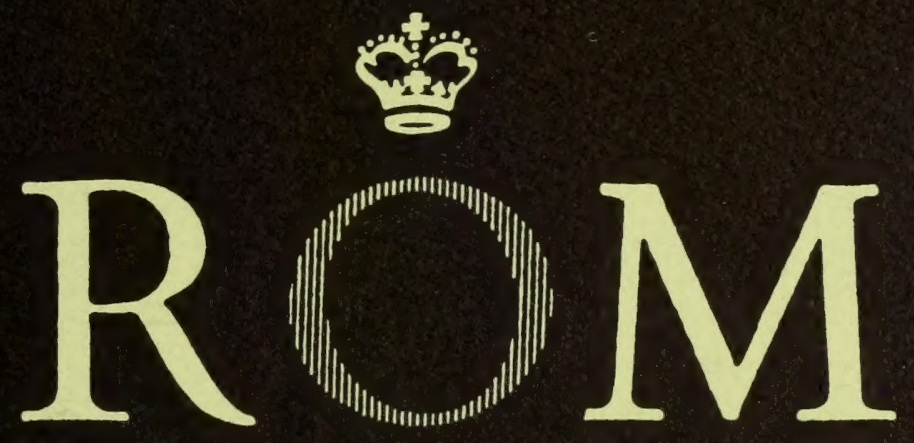




\section{ROYAL ONTARIO MUSEUM LIFE SCIENCES PUBLICATIONS INSTRUCTIONS TO AUTHORS}

Authors are to prepare their manuscripts carefully according to the following instructions. Failure to do so will result in the manuscript's being returned to the author for revision. All manuscripts are considered on the understanding that if accepted they will not be offered for publication elsewhere.

1. GENERAL Papers for publication are accepted from ROM staff members, Research Associates, or from researchers reporting on work done with ROM collections. In exceptional cases, monographic works on the flora and/or fauna of Ontario will be considered for publication by authors not affiliated with the ROM. Authors are expected to write clearly and concisely, and to omit all material not essential for an understanding of the main theme of the paper.

2. FORMAT Manuscripts are to be typed double-spaced (including captions, synonomies, literature cited, and tables) on 11 " $\times 8 \frac{1}{2}$ " paper with a $1 \frac{1}{2}$ " margin on all sides. Three xerox copies are to be submitted to the Chairman of the Editorial Board, and the original retained by the author(s). A separate sheet is to be submitted giving author(s) names, affiliation, title of publication, series in which it is to appear, number of typed pages, number of tables, and number of figures. Manuscripts should normally be organized in the following order: Table of Contents, Abstract, Introduction, Materials and Methods, Results, Discussion, Conclusions, Summary (if paper is long), Acknowledgements, Literature Cited, and Appendices. Authors are encouraged to include foreign language translations of the Summary where appropriate. Headings of sections are to be left-justified to the text margin. The first line of the first paragraph in each new section should not be indented. Text-figures are referred to as "Fig. 1". Literature cited in the text is in the form "Jones (1972)" or "(Jones, 1972)" or "(Smith, 1960:71-79, fig. 17)".

3. STANDARD SOURCES The primary source for decisions on format and style is A Guide for Contributors and Editors of ROM Life Sciences Publications, available from the Chairman of the Editorial Board. Otherwise, consult CBE (AIBS) Style Manual (3rd Edition). Other standard sources are as follows: for English spelling (Concise Oxford Dictionary), for Canadian place names and coordinates (Gazetteer of Canada), and for spelling of geographic names (Times [London] Atlas).

4. ABSTRACT All papers are preceded by a short and factual abstract, about 3 per cent as long as the text, but not longer than 400 words. The abstract is to be followed by four to six keywords enclosed in brackets.

5. TAXONOMY The name of a taxon is given in full in headings, where it appears for the first time, or when the name begins a paragraph. Use authority and date if appropriate, with first mention of each taxon and not thereafter. Taxonomic papers follow the layout in Life Sciences Contribution 99, particularly the synonomies.

6. LITERA TURE CITED References in the text cite author and date and are enclosed in parentheses (Smith, 1978). Complete references are listed in alphabetical order by author at the end of the paper. When there are two or more citations for an author, the works are listed chronologically. Names of journals are not abbreviated. Consult Life Sciences Contributions beginning with 117 for correct bibliographic form.

7. TABLES All tables are numbered consecutively in arabic numerals in numerical order of their first mention in the text. Mark the appropriate text location of each table with a marginal notation. Each table is typed on a separate sheet. Avoid footnotes etc., to tables by building them into the title.

8. FIGURES All figures are numbered consecutively in arabic numerals. Component photographs or drawings are labelled sequentially in upper case letters. Mark the appropriate text location of each figure with a marginal notation. The intended reduction for figures is ideally one and a half to two times. All labelling on figures is in blue pencil and not inked or letraset. Halftones must be photographic prints of high contrast on glossy paper. Authors are to submit 10 " $\times 8^{\prime \prime}$ copies with the MS and retain originals until they are requested. Figure captions are to appear grouped together on a separate page at the end of the MS. 
LIFE SCIENCES CONTRIBUTIONS

ROYAL ONTARIO MUSEUM

NUMBER 129

james P. Bogart Chromosome Studies in Sminthillus from Cuba and Eleutherodactylus from Cuba and Puerto Rico (Anura: Leptodactylidae) 


\section{ROYAL ONTARIO MUSEUM PUBLICATIONS IN LIFE SCIENCES}

The Royal Ontario Museum publishes three series in the Life Sciences:

LIFE SCIENCES CONTRIBUTIONS, a numbered series of original scientific publications including monographic works.

LIFE SCIENCES OCCASIONAL PAPERS, a numbered series or original scientific publications, primarily short and usually of taxonomic significance.

LIFE SCIENCES MISCELLANEOUS PUBLICATIONS, an unnumbered series of publications of varied subject matter and format.

All manuscripts considered for publication are subject to the scrutiny and editorial policies of the Life Sciences Editorial Board, and to review by persons outside the Museum staff who are authorities in the particular field involved.

\section{LIFE SCIENCES EDITORIAL BOARD}

Senior Editor: A.J. BAKER

Editor: C. McGOWAN

Editor: R. WINTERBOTTOM

JAMES P. BOGART is a Research Associate in the Department of Ichthyology and Herpetology, Royal Ontario Museum, and a member of the Department of Zoology at the University of Guelph, Guelph, Ontario.

\section{Canadian Cataloguing in Publication Data}

Bogart, James P., 1940-

Chromosome studies in Sminthillus from Cuba and Eleutherodactylus from Cuba and Puerto Rico (Anura: Leptodactylidae)

(Life sciences contributions, ISSN 0384-8159; no. 129)

Bibliography: $\mathrm{p}$.

ISBN 0-88854-280-1

1. Leptodactylidae-Genetics. 2. BrachycephalidaeGenetics. 3. Amphibians-Cuba-Genetics. 4. Amphibians-Puerto Rico-Genetics. 5. Chromosomes.

I. Royal Ontario Museum. II. Title. III. Series.
QL668.E257B63
$597.8 ’ 7$
C81-094959-8

Publication date: 6 November 1981

ISBN 0-88854-280-1

ISSN 0384-8159

(C) 1981, The Royal Ontario Museum

100 Queen's Park, Toronto, Ontario, Canada M5S 2C6

PRINTED AND BOUND IN CANADA AT THE ALGER PRESS 


\title{
Chromosome Studies in Sminthillus \\ from Cuba and Eleutherodactylus \\ from Cuba and Puerto Rico \\ (Anura: Leptodactylidae)
}

\begin{abstract}
Chromosomes from 20 species of Eleutherodactylus from Puerto Rico and Cuba as well as chromosomes of Sminthillus limbatus from Cuba were analysed and compared. Puerto Rican Eleutherodactylus have 26- or 30-chromosome karyotypes which may reflect two separate ancestral invasions. Cuban Eleutherodactylus species have 18-, 28-, 30-, and 32-chromosome karyotypes which may be related to three chromosomal groupings and possibly three separate invasions into Cuba. Sminthillus limbatus is karyotypically similar to ricordi group members of Eleutherodactylus in Cuba and, chromosomally, there is little justification for its generic distinction. Some of the chromosomal groupings correspond to morphologically determined species groups and have affinities with mainland species of Eleutherodactylus or Syrrhophus. The apparently rapid chromosomal evolution in Eleutherodactylus is unusual in the Anura and should be useful for examining general mechanisms of chromosomal evolution as well as the ecological and genetic significance of chromosomal variation. Preliminary results are presented for C-banded Eleutherodactylus chromosomes which reveal densely staining telomeres and interstitial constitutive heterochromatin.
\end{abstract}

\section{Introduction}

The genus Eleutherodactylus is a highly diverse group of terrestrially developing leptodactylid frogs which has undergone rapid speciation in the New World tropics and subtropics. Lynch and Duellman (1980) suggested that the genus includes more than 400 species. Approximately 340 species have been recognized and grouped into 17 species groups (Lynch, 1976). Evolutionary relationships in the genus are complex because of the overwhelming number of species, the intraspecific variation evident in many species (Cochran and Goin, 1970; Goin, 1947, 1954; Lynch, 1967; Lynch and Duellman, 1980; Rivero, 1978; Schwartz, 1973, 1974, 1976), and the lack of taxonomic characteristics that can be applied to all the species over their entire ranges. The characters used to define species groups in the West Indies are not useful to define groups in South and Central America (Lynch, 1976). 


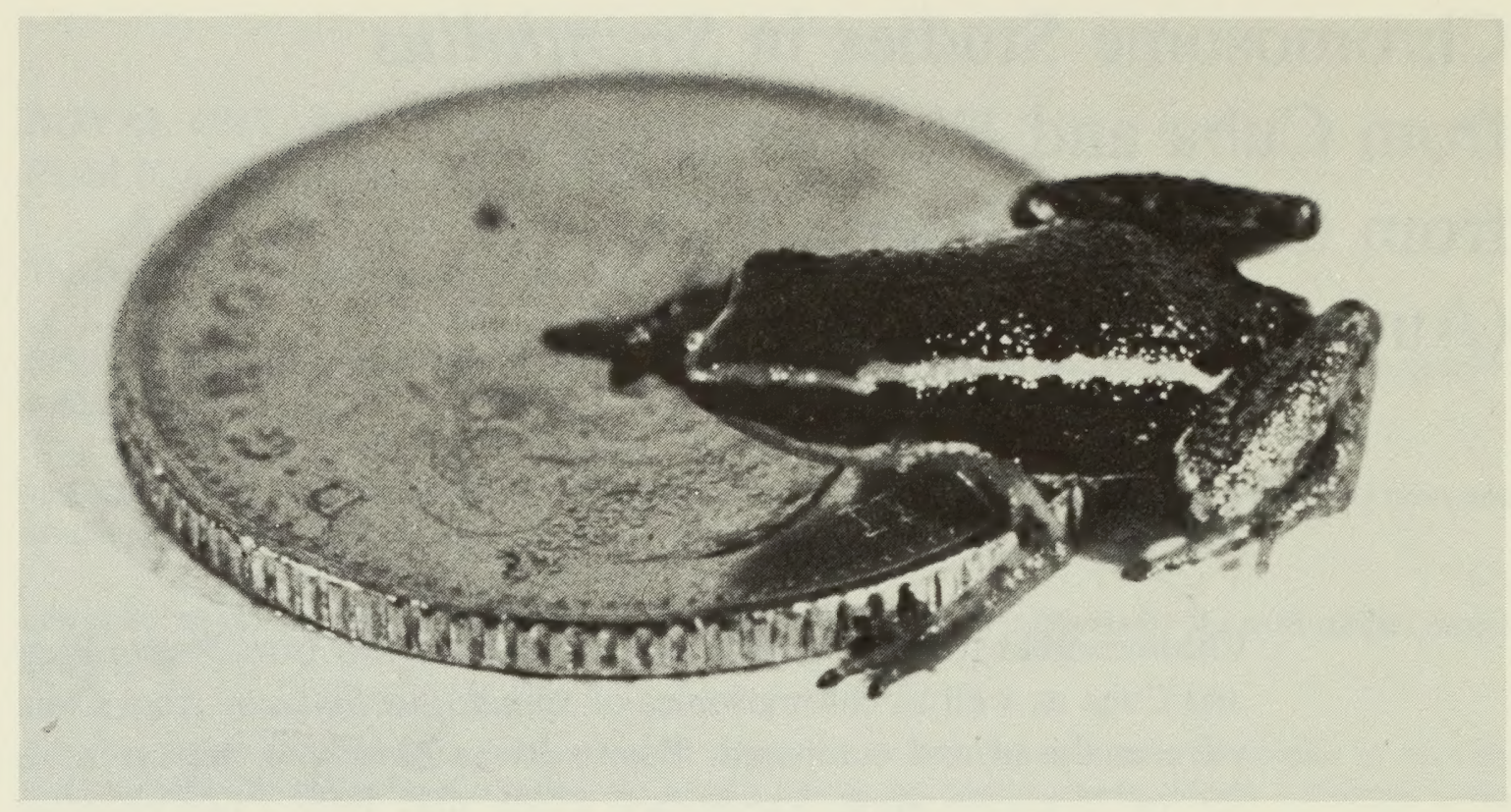

Fig. 1. An adult specimen of Sminthillus limbatus from Cuba on an $18 \mathrm{~mm}$ ten-cent coin.

Although the chromosomes analysed so far are from a small percentage of the species, variation with respect to chromosome numbers and chromosome morphology (Bogart, 1970, 1973b) in the genus is extreme. The numbers of chromosomes range from a low of $18(2 n)$ to a high of $36(2 n)$ and species with intermediate numbers of $20,22,26,30,32$, and 34 are known. Centromeric ratios vary considerably and many telocentric chromosomes exist in some species. I suggest (Bogart, 1973b) that karyotypic analyses may be very useful in defining species groupings and evolutionary trends in this genus.

The present investigation involves Eleutherodactylus species from Cuba and Puerto Rico as well as Sminthillus limbatus from Cuba. All these species would be included in Lynch's (1971) Alpha division of eleutherodactyline frogs.

\section{Materials and Methods}

Chromosomes from most of the Puerto Rican specimens were obtained from corneal epithelial tissue with in vitro colchicine treatment (Bogart, 1968, 1973a). Chromosome preparations from Eleutherodactylus cooki and E. karlschmidti were prepared by Dr. George Drewry in Puerto Rico using Patton's (1967) methods. Chromosomes from the Cuban specimens were obtained in the field using a slightly modified technique. The Cuban frogs were collected and held for one to three days in plastic bags. The frogs were injected with colchicine solution $\left(1 \mathrm{mg} / \mathrm{cm}^{3}\right)$ by passing a hypodermic needle under the skin from the upper thigh to penetrate the dorso-lymphatic sacs. The amount of colchicine solution varied. Colchicine was injected until the skin between the eyes bulged slightly (about 0.25 to $0.5 \mathrm{~cm}^{3}$ for these small frogs). Some 6 to $8 \mathrm{~h}$ after injection, the frogs were pithed and the eyes 
were removed and placed in a small amount of distilled water in a spot depression plate for $1 \mathrm{~h}$. The eyes were then suspended over glacial acetic acid for $30 \mathrm{~s}$ and put back in distilled water for about $1 \mathrm{~min}$. The tissue over the surface of the eye was pinched off with watch-maker's forceps and placed on a cleaned, silicon-treated cover slip with a drop of 70 per cent acetic acid. The cover slip was applied to a precleaned slide and squashed under a band of bibulous paper using thumb pressure. The cover slip was sealed with Kroenig cover-glass cement applied with a spatula which had been heated with a candle. These temporary slides were transported to Guelph and viewed with phase contrast optics. Suitable figures were photographed with high contrast film. The cover slips were removed by submerging the slide in liquid nitrogen until the boiling ceased, brushing off the frozen cement, and flicking the cover slip off with a razor blade. The slides were dehydrated in two changes of 3:1 methanol: acetic acid for 2 to $4 \mathrm{~min}$ and air dried at room temperature.

The air-dried preparations were further treated to demonstrate C-bands using a modification of the methods described by Sumner (1972). Slides were air dried for at least a week, soaked overnight in fresh $3: 1$ methanol:acetic acid at $4^{\circ} \mathrm{C}$, allowed to dry for one $\mathrm{h}$, immersed in saturated $\mathrm{BaOH}$ solution $\left(4 \mathrm{~g}\right.$ in $100 \mathrm{~cm}^{3}$ water) at $40^{\circ} \mathrm{C}$ for $12 \mathrm{~min}$, and rinsed four times in water. The final rinse was acidified with acetic acid $\left(4\right.$ drops in $\left.50 \mathrm{~cm}^{3}\right)$. The slides were then immersed in $2 \mathrm{X}$ Standard Sodium Citrate Buffer (SSC) at $60^{\circ} \mathrm{C}$ for $1 \mathrm{~h}$, rinsed three times in water and once in Sorensen's phosphate buffer ( $\mathrm{pH} \mathrm{6.8)}$. The slides were stained for $8 \mathrm{~min}$ in the same buffer ( $\mathrm{pH}$ 6.8) containing 4 per cent Giemsa (Gurr). After rinsing the slides four times in deionized water, and drying them for one day at room temperature, a cover slip was mounted using Permount.

Several spreads from each individual were observed and their chromosome complements counted under the microscope. The best three chromosome spreads were selected for analysis. Computer assisted analyses were performed using programs described by Green et al. (1980). Karyotypes were arranged to conform to the computer-drawn idiograms.

The Puerto Rican specimens used in the present study are deposited in the Texas Natural History Collection (TNHC) of the Texas Memorial Museum in Austin with the exception of the individuals used by Dr. George Drewry for chromosome preparations performed in Puerto Rico. The Cuban material is deposited in the Royal Ontario Museum (ROM). The specimens used are:

Eleutherodactylus antillensis (Reinhardt and Lütken)-2 $\hat{o} \widehat{o}$ from El Verde field station, $3.2 \mathrm{~km} \mathrm{~S}$ of El Verde, Barrio Rio Grande, Puerto Rico.

E. atkinsi Dunn-1 + from Parque Almandares, Havana, Cuba.

E. auriculatus (Cope) -4 juveniles from Soroa, Pinar del Río, Cuba.

E. brittoni Schmidt-2 $0 \hat{\sigma}$ from El Verde field station, $3.2 \mathrm{~km} \mathrm{~S}$ of El Verde, Barrio Rio Grande, Puerto Rico.

E. cooki Grant-Puerto Rico. Specimens were collected and prepared for chromosomes by Dr. George Drewry.

E. coqui Thomas-3 $0 \hat{0}$ and 1 우 from El Verde field station, $3.2 \mathrm{~km} \mathrm{~S}$ of El Verde, Barrio Rio Grande, Puerto Rico.

E. cuneatus (Cope)— 4 ổ and 2 juveniles from Moncada, Pinar del Río, Cuba, and 1 $\hat{o}$ and 4 juveniles from Soroa, Pinar del Río, Cuba. 
E. dimidiatus (Cope) (Fig. 1) $-1 \hat{\delta}$ and 1 juvenile from Soroa, Pinar del Río, Cuba.

E. eneidae Rivero-1 $\hat{0}$ from El Verde field station, $3.2 \mathrm{~km} \mathrm{~S}$ of El Verde, Barrio Rio Grande, Puerto Rico.

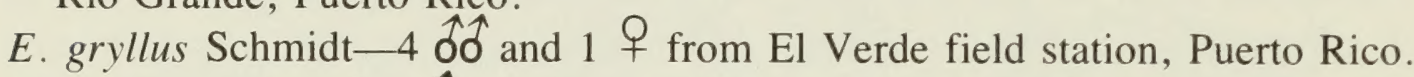

E. hedricki Rivero-1 $\hat{o}$ and 1 juvenile from El Verde field station, Puerto Rico.

E. karlschmidti Grant-Puerto Rico. Specimens were collected and prepared for chromosomes by Dr. George Drewry.

E. klinikowskii Schwartz-2 $0 \hat{o ̂}$ and 2 juveniles from Moncada, Pinar del Río, Cuba.

E. locustus Schmidt-4 $\hat{\text { ô }}$ and 1 O, $4.8 \mathrm{~km}$ from El Verde field station, Barrio Rio Grande, Puerto Rico.

E. planirostris (Cope)-E. p. planirostris (Cope) -1 의 from Tampa, Florida; and 1 0 and $1+$ from Havana, Cuba. E. p. goini Schwartz-1 + and 3 juveniles from Moncada, Pinar del Río, Cuba; and 1 juvenile from Soroa, Pinar del Río, Cuba.

E. richmondi Stejneger-3 $\hat{\text { ô }}$ from El Verde field station, $3.2 \mathrm{~km} \mathrm{~S}$ of El Verde, Puerto Rico.

E. unicolor Stejneger-1 $0 \hat{\mathrm{O}}$ and 2 9 + collected by Dr. George Drewry, Puerto Rico.

E. varians (Gundlach and Peters) - 1 juvenile from Moncada, Pinar del Río, Cuba.

E. wightmanae Schmidt-1 $\hat{\delta}$ from El Verde field station, $3.2 \mathrm{~km} \mathrm{~S}$ of El Verde, Puerto Rico.

E. zugi Schwartz-1 + , $1 \hat{0}$, and 4 juveniles from Soroa, Pinar del Río, Cuba.

Sminthillus limbatus (Cope) (Fig. 1) $-1+$ and 4 juveniles from Soroa, Pinar del Río, Cuba.

\section{Results}

Chromosomes were found to vary in number and in morphology among the species examined from both islands. The Puerto Rican species have 26- and 30-chromosome karyotypes $(2 n)$ but $18,28,30$, and 32-chromosome species were found in Cuba. Chromosomal analyses for the Puerto Rican species are provided in Table 1 and the idiograms from these species, derived from the data in Table 1, are presented in Figs. 2 and 3. The analyses for the Cuban species are provided in Table 2 and idiograms are included in Figs. 4 and 5. Karyotypes for the Puerto Rican species are provided in Fig. 6 and the karyotypes of the Cuban species are included in Fig. 7. Three C-banded karyotypes are presented in Fig. 8 and interpreted on the idiograms in Fig. 9. The same spread was used for the karyotype (Fig. 7A) and C-bands (Fig. 8A) for $E$. auriculatus.

Most specimens provided many well-spread figures but some of the specimens provided only a few chromosome spreads that were of suitable quality for analysis. Sminthillus limbatus is, perhaps, the smallest of all anurans and was difficult to prepare in Cuba without the aid of a binocular dissecting microscope. The seemingly larger chromosomes obtained from S. limbatus (Fig. 7G) and some of the other very small specimens such as E. dimidiatus (Fig. 7D), E. zugi (Fig. 7F), or E. unicolor (Fig. 6L) are possibly artifacts. The cells in very small amounts of tissue apparently respond more rapidly and thoroughly to the hypotonic treatment so that the subsequent squashing spreads the cells and stretches the chromosomes to a greater degree than in specimens that had larger eyes and provided more tissue. Relative DNA quantities were not obtained to substantiate this observation. 

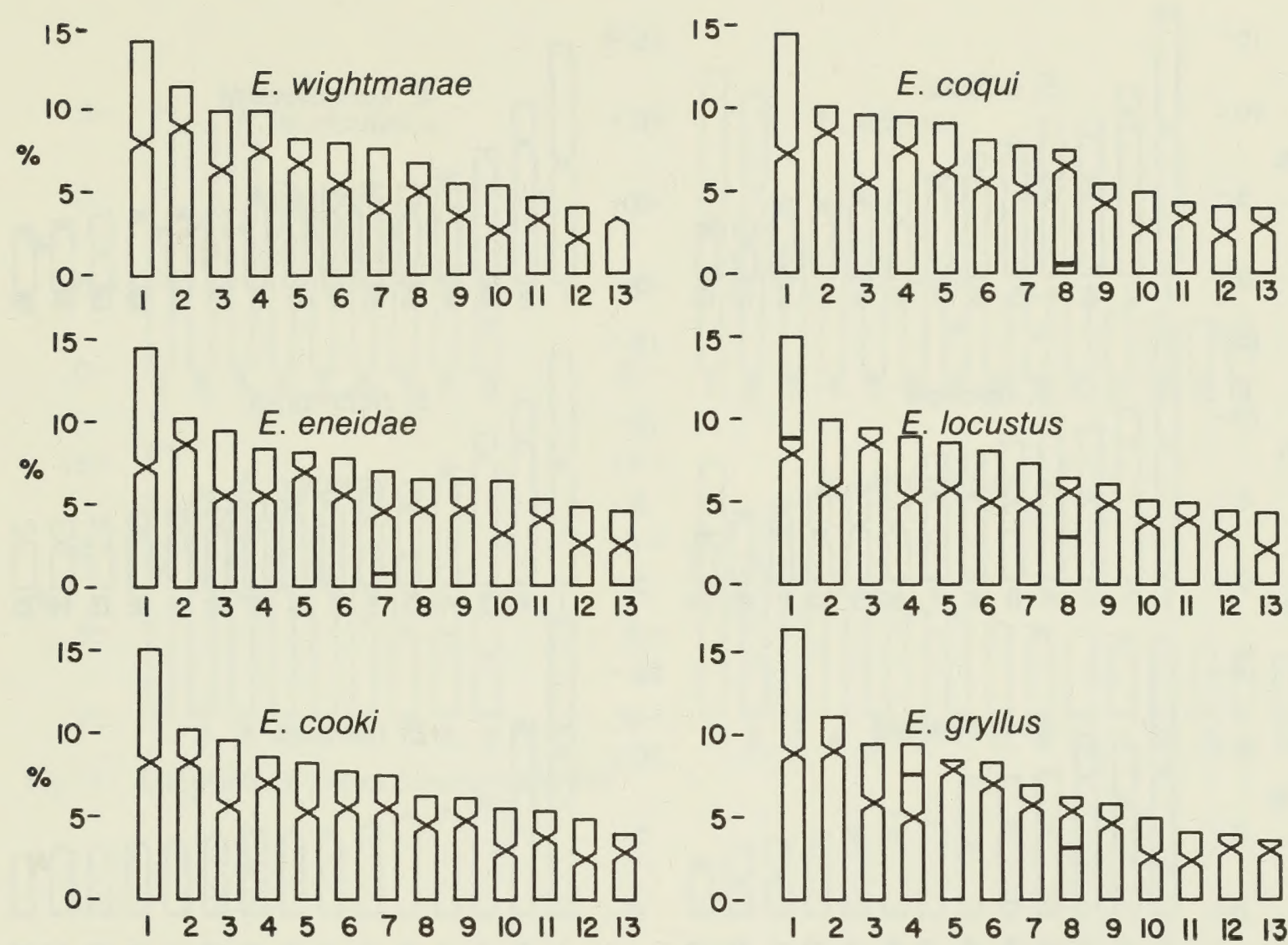

Fig. 2. Idiograms of Puerto Rican Eleutherodactylus. The per cent axis refers to the relative length of each chromosome in relation to the total haploid genome length. Secondary constrictions are included as bars at the positions where they were found to occur.

Only a few satisfactory C-banded preparations were obtained using the present method (Fig. 8). Many slides did not reveal differential staining of the chromosomes. Even when C-bands were obtained after many attempted variations in technique, some figures on the same slide were not banded. Success was predictable if the treated slide initially contained numerous spreads, a variety of contracted states of the chromosomes between spreads, and the chromosomes were "dense" in air-dried preparations prior to treatment with $\mathrm{BaOH}$. Dense chromosomes glow in the dried preparations when viewed with dry phase contrast optics.

\section{Chromosome Groups}

The chromosome numbers and morphology varied considerably among the species sampled from both islands, but there are some interesting similarities which may be used to show relationships among the species. The only 18 -chromosome species, $E$. auriculatus and E. varians, are both included in the auriculatus group by Schwartz (1969). No other auriculatus group members were examined here but $E$. diastema and E. podociferus of Costa Rica also have 18 chromosomes (Bogart, 1970). These Costa Rican Eleutherodactylus would be included in Lynch's (1976) unistrigata group. He indicated that the unistrigata group may not prove to be separable from the auriculatus group. However, among the 92 South American species included in his unistrigata group, Lynch (1976) listed species with 34- (E. variabilis and E. 

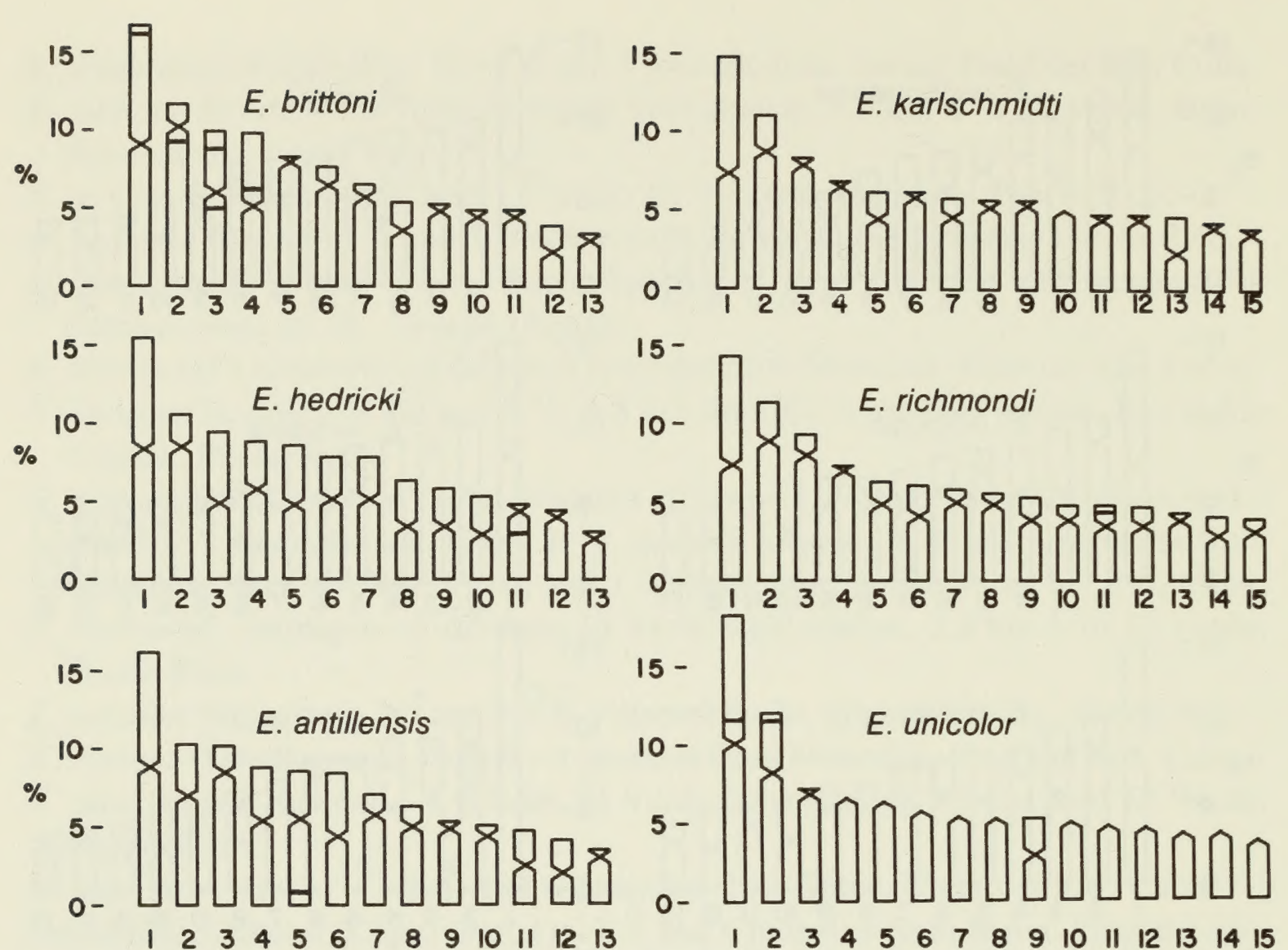

Fig. 3. Idiograms of Puerto Rican Eleutherodactylus.

conspicillatus) and 36-chromosome karyotypes (E. ventrimarmoratus) (Bogart, 1970, 1973b). Eleutherodactylus cuneatus, E. klinikowskii, E. planirostris, and E. zugi all have 32 chromosomes, a number not found to date in any other Eleutherodactylus species. E. ricordi figured by Bogart (1973b), is a synonym of $E$. planirostris (Schwartz, 1974). None of the 32-chromosome species has the large pair of metacentric chromosomes found in all the Puerto Rican species and the other Cuban species studied. All four 32-chromosome Eleutherodactylus species would be included in the ricordi group by Dunn (1926) and Lynch (1976). E. atkinsi is also included in the ricordi group by Dunn (1926) but this species is karyotypically distinct from the other species examined in the ricordi group and is the only species with 28 chromosomes as well as two large pairs of metacentric or submetacentric chromosomes.

Eleutherodactylus dimidiatus has a 30-chromosome karyotype which is unlike all other Cuban species examined. This is also the only known 30-chromosome eleutherodactyline species which has only one metacentric chromosome pair (No. 1). Dunn's (1926) dimidiatus group included only two Cuban species, E. dimidiatus and E. emiliae. This group would correspond to Schwartz's emiliae group (Lynch, 1976).

E. emiliae has not been karyotyped.

Sminthillus limbatus was described as a dendrobatid by Barbour and Noble (1920) and was included by Noble (1931) in his Brachycephalidae. Noble indicated that the species had eleutherodactyline affinities, a finding more recently affirmed by Griffiths (1959), Lynch (1971), Heyer (1975), and Ardila-Robayo (1979). Lynch (1971) stated that $S$. limbatus is most similar to the auriculatus or dimidiatus groups. 

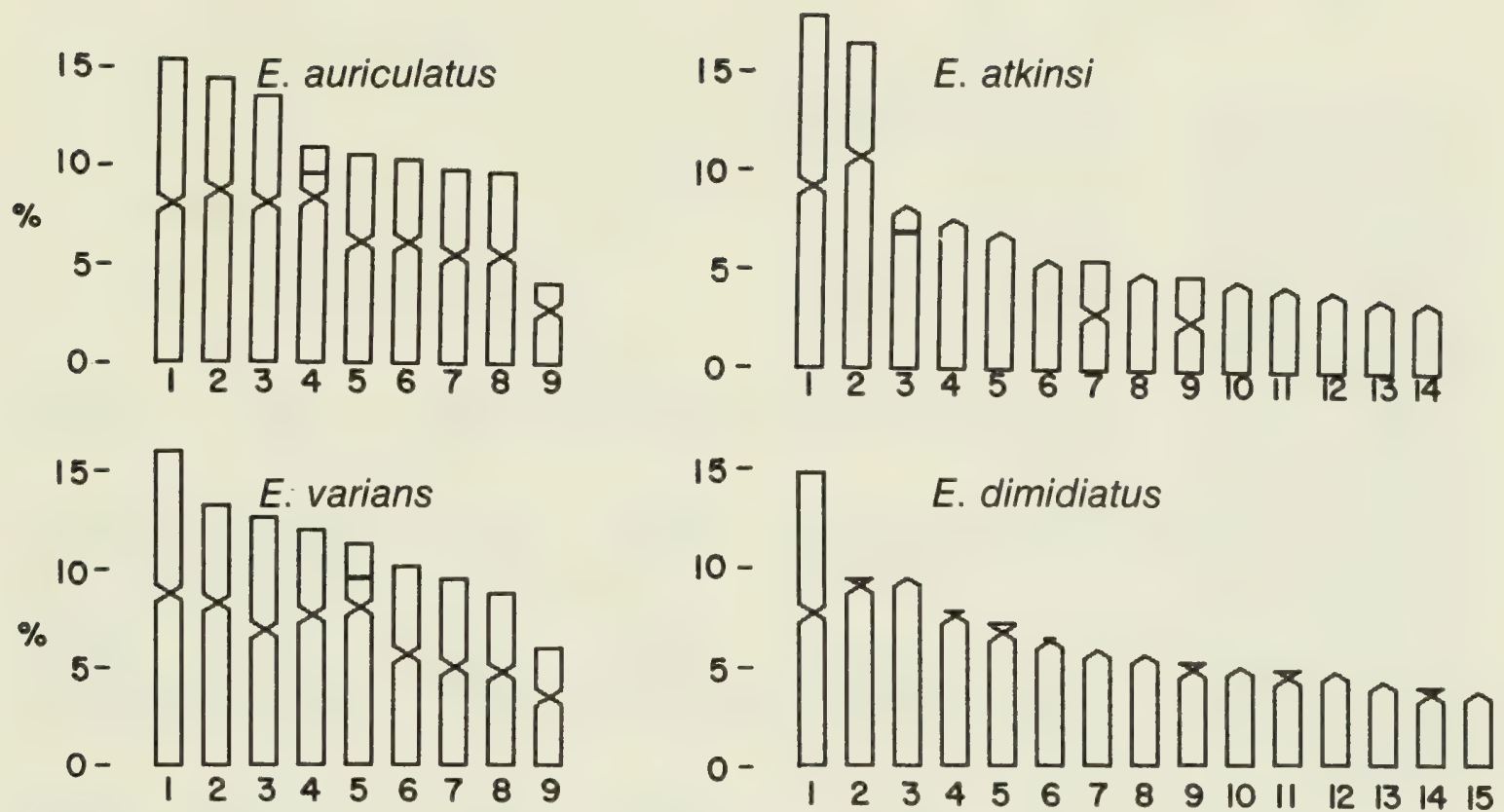

Fig. 4. Idiograms of Cuban Eleutherodactylus.

This species is restricted to Cuba and is believed to be the world's smallest frog. Females lay a single, large egg (Noble, 1931). S. limbatus has a karyotype similar to that of the Cuban ricordi group members (except $E$. atkinsi). It is unlike any of the species of the auriculatus or dimidiatus (=emiliae) groups examined.

Puerto Rican Eleutherodactylus have 26- or 30-chromosome karyotypes. The idiograms and karyotypes are grouped subjectively (Table 1; Figs. 2, 3, 6) according to the following criteria, listed in order of presumed importance: (1) chromosome number, (2) increasing length of chromosome No. 1, (3) general similarities of metacentric and submetacentric chromosomes, and (4) increasing number and position of telocentric chromosomes. Secondary constrictions appear in a variety of positions with as many as five secondary constrictions in E. brittoni. E. wightmanae, $E$. cooki, and E. karlschmidti did not demonstrate secondary constrictions in the spreads examined. The eighth chromosome of E. locustus and E. gryllus (Fig. 2) has similar secondary constrictions and morphologies, which could provide evidence for relationship between these two species. The karyotype of $E$. portoricensis was published by Bogart (1973b). But, it was later determined (G. Drewry, pers. comm.) that the specimens used (TNHC 36379 and 36380) were, in fact, E. coqui. I have additional material from specimens considered to be $E$. portoricensis and their karyotypes are basically identical to those of $E$. coqui. I prefer to await additional material from $E$. portoricensis in order to confirm this finding.

Based on chromosome number, the Puerto Rican 30-chromosome species are distinct and are probably related. E. karlschmidti and E. richmondi share many chromosomal similarities and are probably closely related, although Schwartz (1976) believes, on the basis of morphological and biogeographical considerations, that $E$. richmondi is a peripheral member of the ricordi group. E. unicolor has 30 chromosomes but has more single-armed chromosomes and appears to be karyotypically distinct from the other 30-chromosome species. E. unicolor is the smallest Puerto Rican species examined and E. karlschmidti is the largest. 


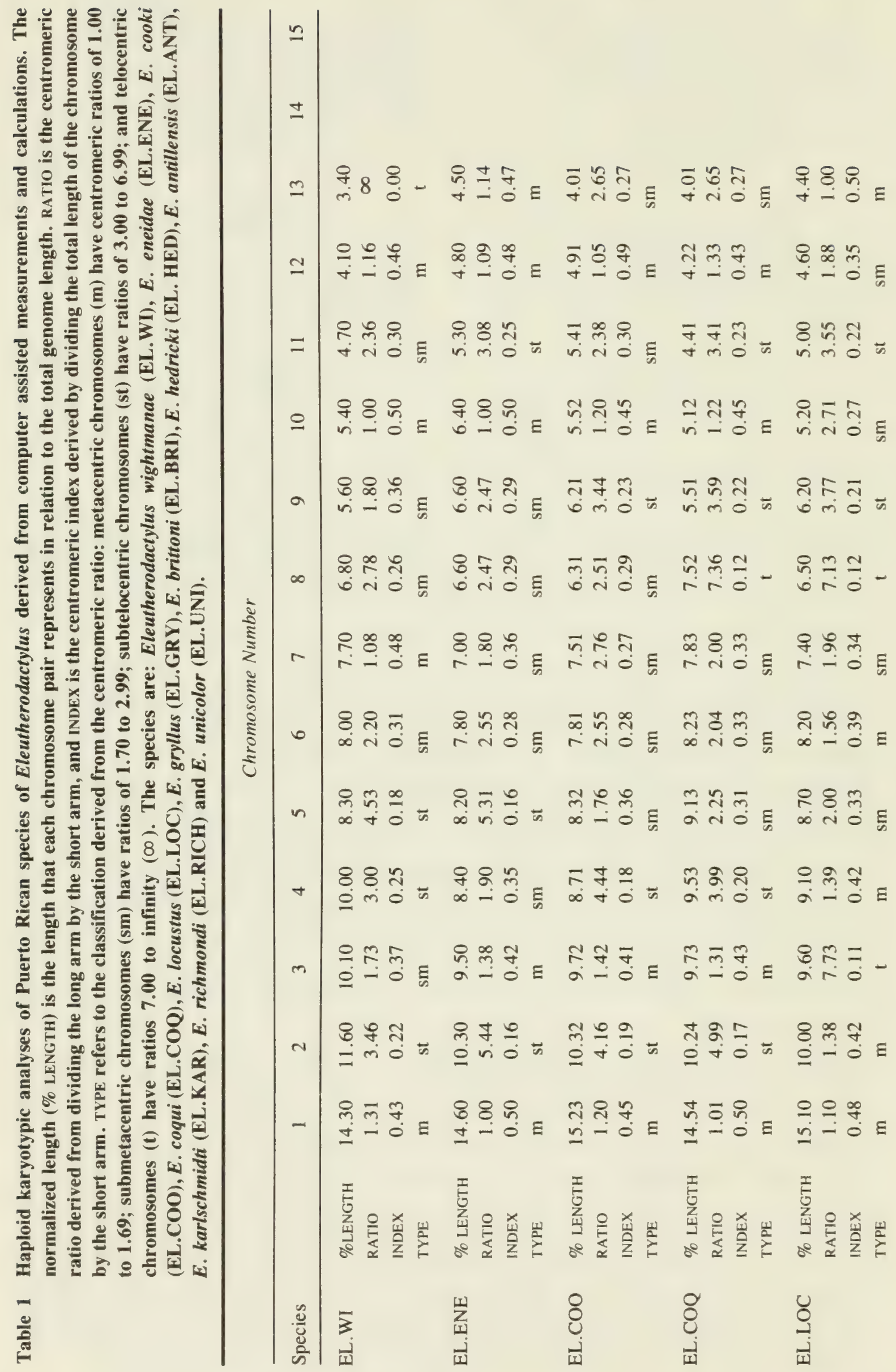




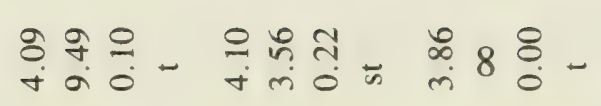

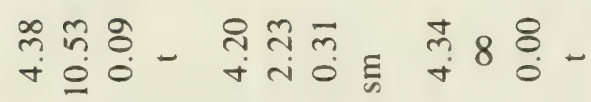

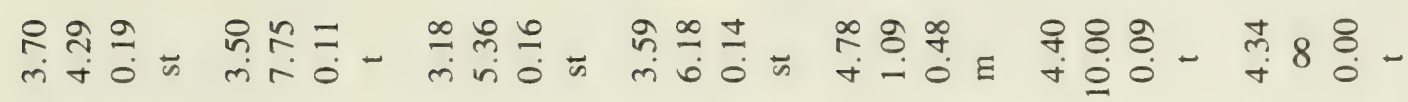
윰ำ

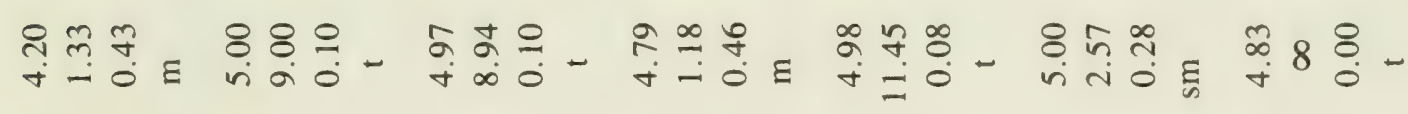

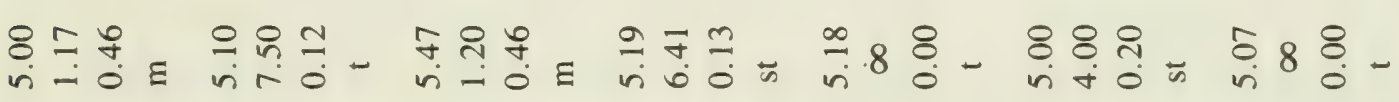

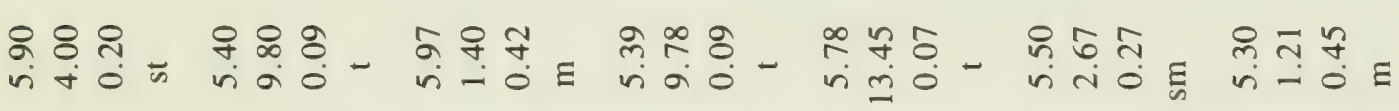

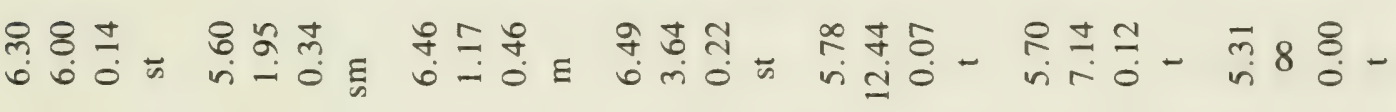

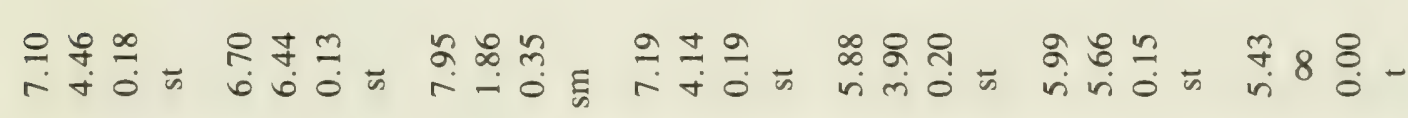

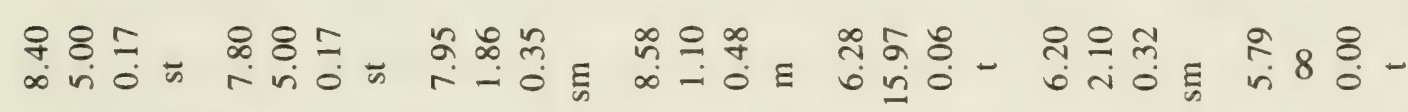

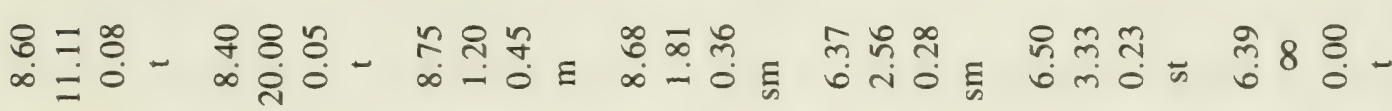

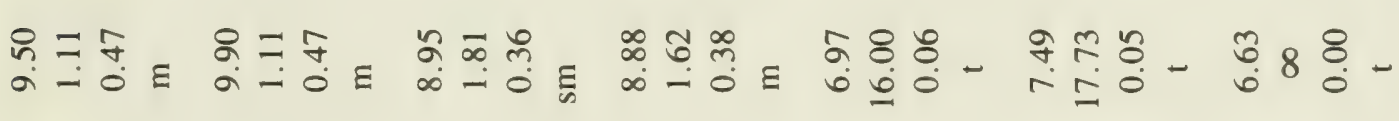

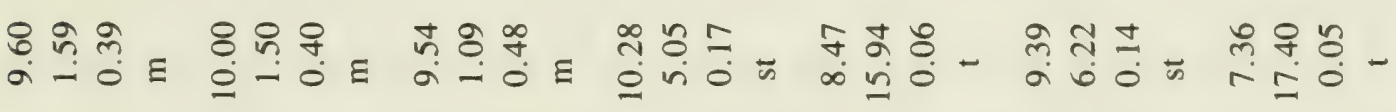

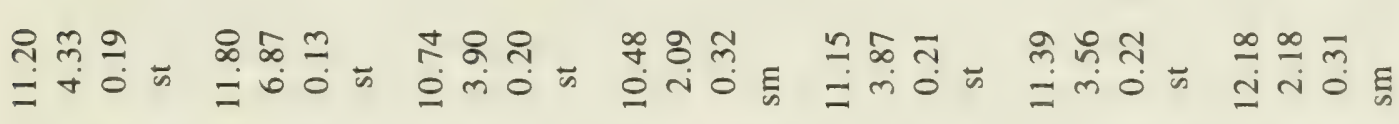

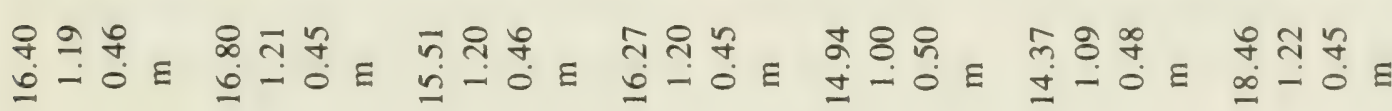

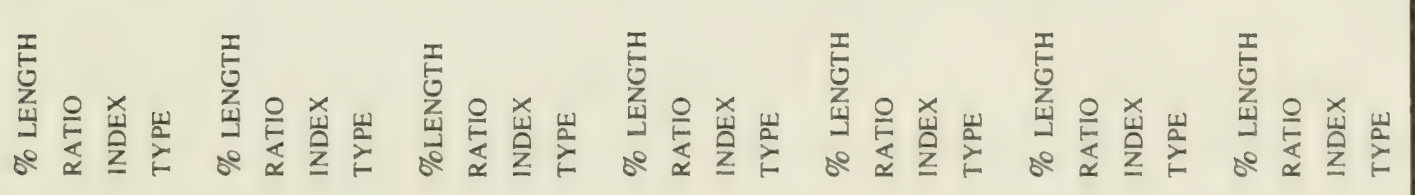

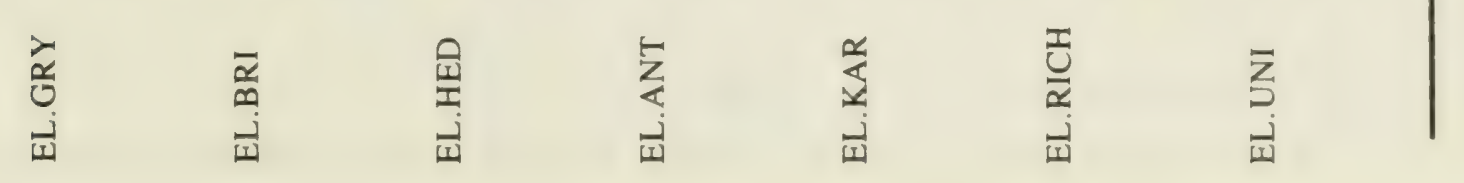



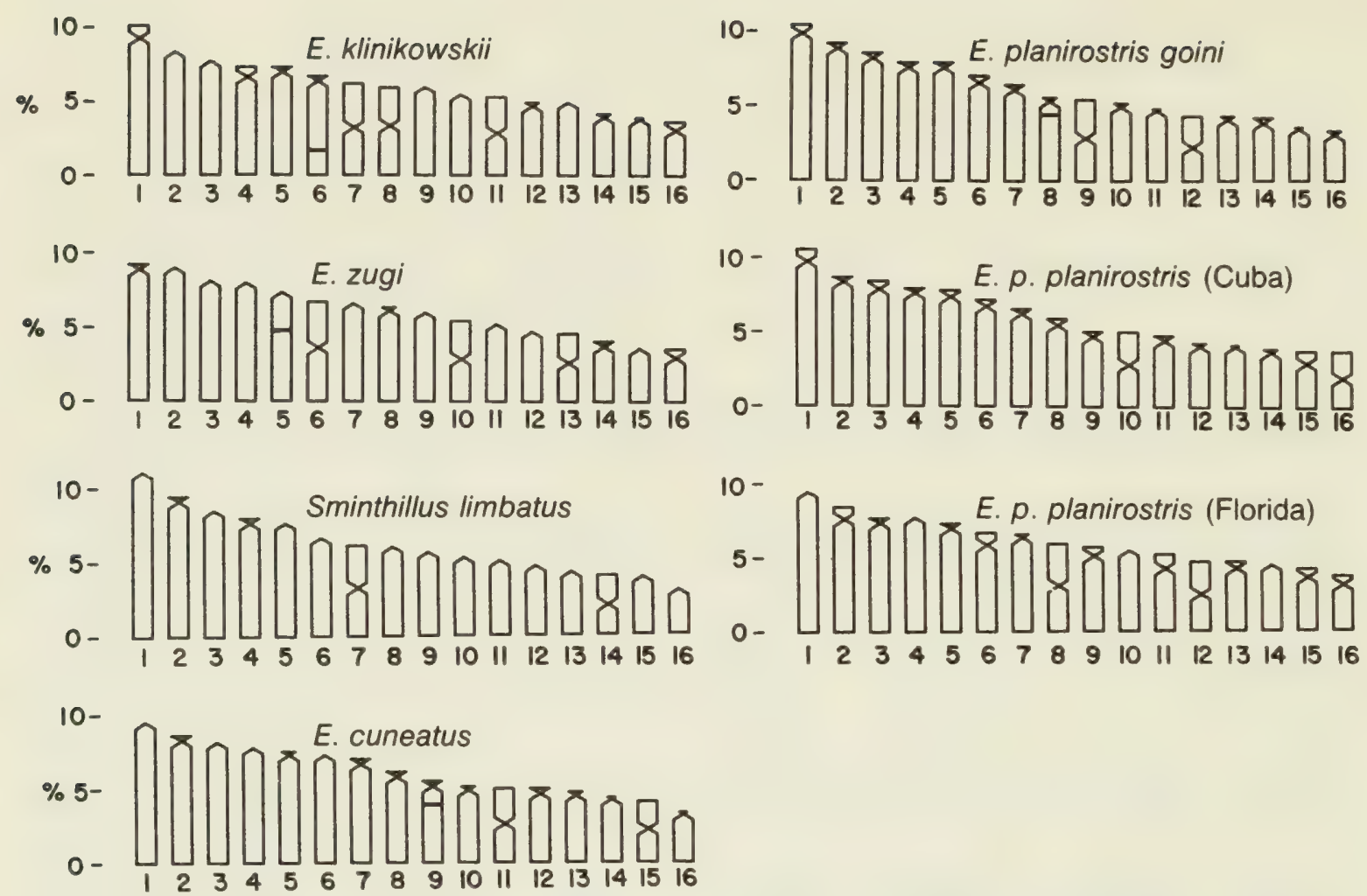

Fig. 5. Idiograms of Cuban Eleutherodactylus and Sminthillus limbatus.

\section{Chromosome Bands}

The chromosome variation seen in Eleutherodactylus may be amenable to analyses using banding techniques. Centric fusions and fissions or translocations which have involved constitutive heterochromatin have been revealed with C-bands (Ohno, 1974). Schmid (1978a) identified three classes of constitutive heterochromatin using C-bands and fluorescence in Bufo and Hyla. These anurans have a higher frequency of constitutive heterochromatic regions than have other vertebrate classes (Schmid, 1978a). None of the hylids, bufonids, ranids, microhylids, or rhacophorids that Schmid (1978a, 1978b) examined had telocentric chromosomes nor were they related through putative fusion-fission phenomena. Schmid found that most of the telomeres in the species he examined showed only weak C-banding. Most of the telomeres in Eleutherodactylus species shown in Figs. 8 and 9 had C-bands that were as intensely stained as the centromeres. Some differences were encountered in the C-bands of the pericentric heterochromatin. The metacentric chromosomes in E. cuneatus (Nos. 11 and 15, Figs. 8C and 9) demonstrated $\mathrm{C}$-bands on either side of the centromere, a condition similar to chromosomes 8 and 11 in E. klinikowskii, but the third metacentric chromosome (No. 7) in E. klinikowskii had a C-band only on one side of the centromere. If a fusion had occurred, metacentric chromosomes might be expected to have additional pericentric heterochromatin and might even be dicentric-characteristics that would be similar to Robertsonian metacentrics in human chromosomes (Daniel and Lam-Po-Tan, 1976). Such additional pericentric C-bands were not found in 18-chromosome E. auriculatus.

Interstitial C-bands were found in some chromosomes of all three species. The bands on chromosome 4 in E. auriculatus and chromosome 9 in E. cuneatus relate to the secondary constrictions found in the unbanded karyotype (Fig. $7 \mathrm{~A}$ and $7 \mathrm{H}$ ). In addition to the strong $\mathrm{C}$-bands, weak $\mathrm{C}$-banded telomeres were found in some 
chromosomes of E. klinikowskii (Nos. 9 and 10) and E.cuneatus (Nos. 11, 15, and 16). No telomeric C-bands were found to be associated with the metacentric chromosome No. 11 in E. klinikowskii. Although inferences may be arrived at concerning interspecific homologies between the species with respect to the C-bands observed, they will be more meaningful when additional species, as well as different populations of the same species, can be compared.

\section{Discussion}

\section{Karyotypic Variation}

The evident variation in Eleutherodactylus karyotypes among the West Indian frogs suggests that the variation found among Central and South American species (Bogart, $1970,1973 \mathrm{~b}$ ) is not an artifact of species sampling but a characteristic present throughout the genus. The number of telocentric chromosomes is highest among those species possessing the largest number of chromosomes, a fact which indicates that karyotypic evolution has involved centric fissions or fusions. Previously examined species (Bogart, 1970) could be related to a fission-fusion continuum having end points of 18 metacentric or submetacentric chromosomes, as previously found in $E$. diastema and $E$. podiciferus from Costa Rica, and 36 telocentric chromosomes, as found in E. ventrimarmoratus from Peru (Bogart, 1970, 1973b). Intermediate chromosome numbers may be explained by assuming either, that various centric fusions took place from an ancestral karyotype with telocentric chromosomes or, that centric fissions produced intermediate numbers and derived karyotypes would possess a greater number of telocentric chromosomes.

Robertsonian rearrangements have been used to describe evolutionary trends in a number of animal groups (Dingerkus, 1979; Gorman, 1973; Matthey, 1973; Patton, 1967) and are usually analysed by simply counting the number of chromosome arms. The total number of arms was termed the "nombre fundamental" (N.F.) and was used by Matthey $(1945,1949)$ in a karyosystematic investigation of lizards. The N.F. for Eleutherodactylus appears from previous studies to be 36 (Bogart, 1970, 1973b). Some of the species in the present study, such as E. atkinsi, E. cuneatus, E. planirostris, E. unicolor, and Sminthillus limbatus, also conform to this pattern. There are, however, several problems relating to this method of analysis. The earlier studies (Robertson, 1916; Matthey, 1945, 1949) did not have the benefit of colchicine induced metaphase configurations. Their figures, derived from sectioned material and camera lucida drawings, do not reveal very small arms or the structural detail possible to resolve now. Is it necessary to count all visible arms regardless of size or is there a size at which a small arm may be ignored? This problem has been circumvented by replacing Matthey's term "rod" chromosome with the ill-defined term "acrocentric" and applying the latter to those chromosomes with very small or with terminal centromeres. Numbers of metacentric and telocentric chromosomes in species may be altered by pericentric inversions or translocations and there are numerous examples of these chromosomal mutations (White, 1973). Cytologists have also argued that centromeres may be lost but not gained and so karyotypic evolution has progressed from a large number of telocentric chromosomes to a smaller number of metacentric 


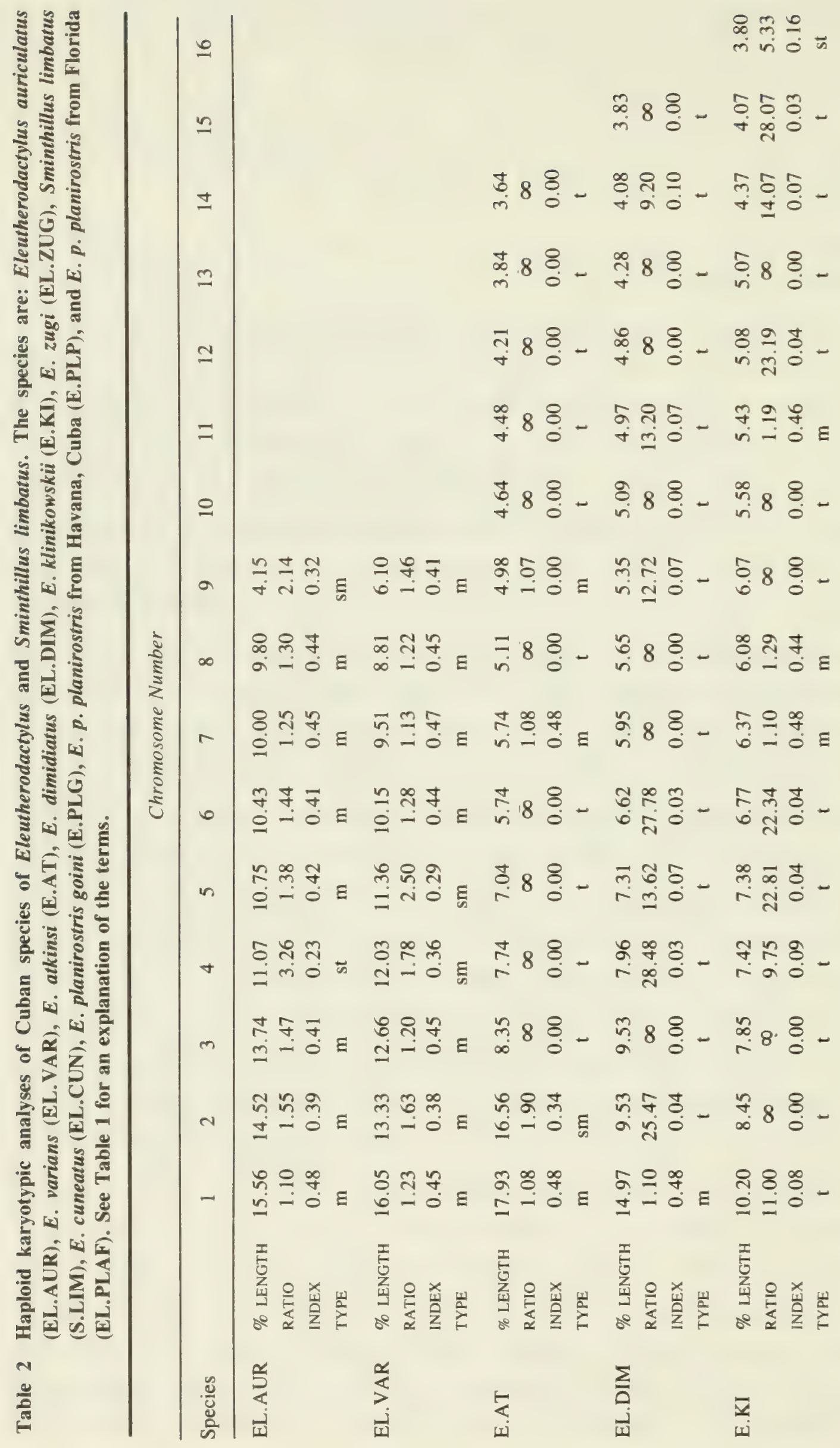




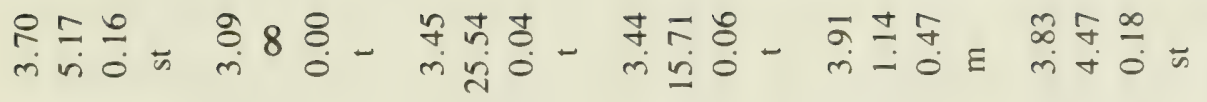
mim

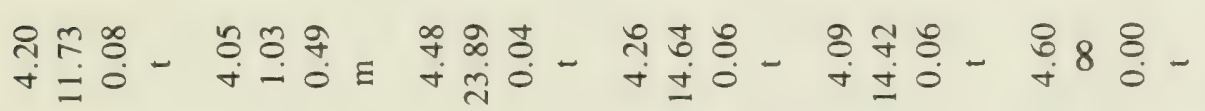

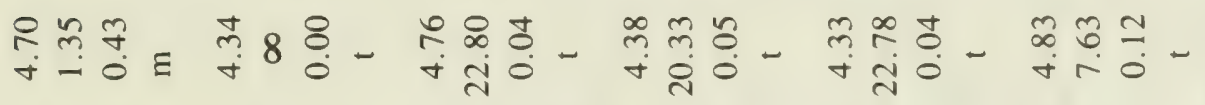

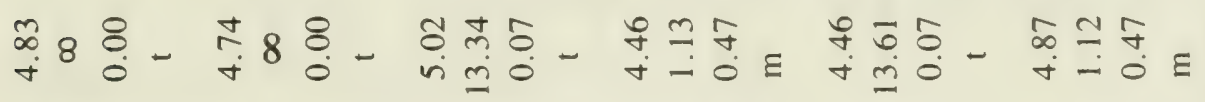
స్ㅇ 8 \&

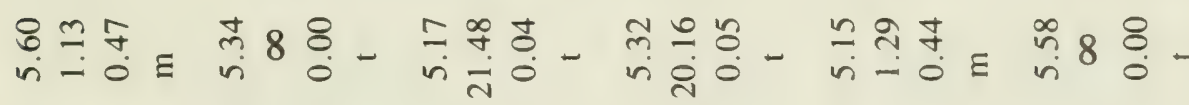

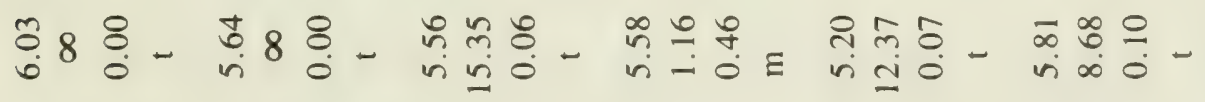

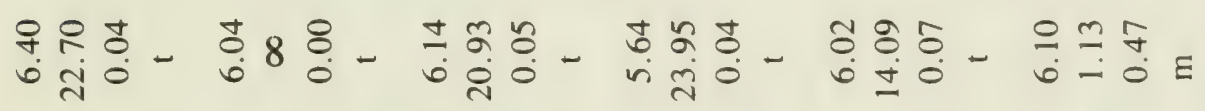

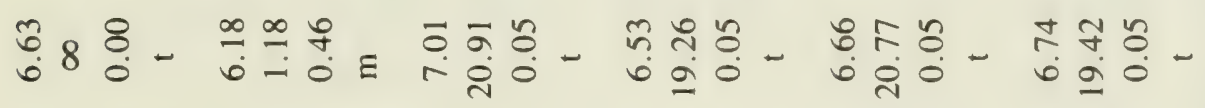

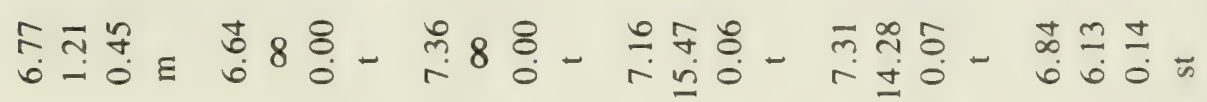

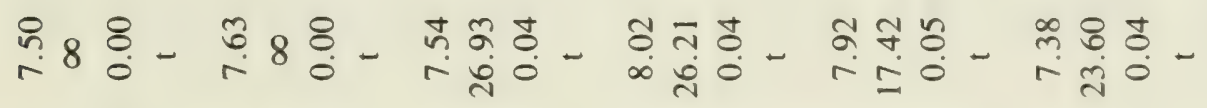

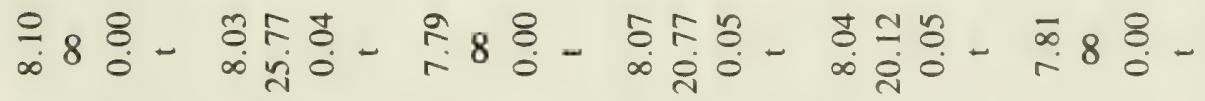

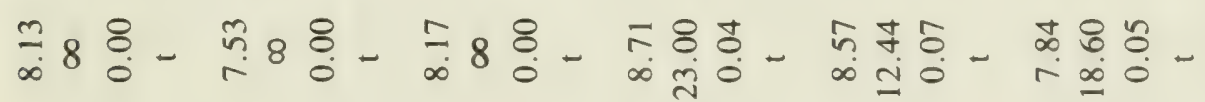

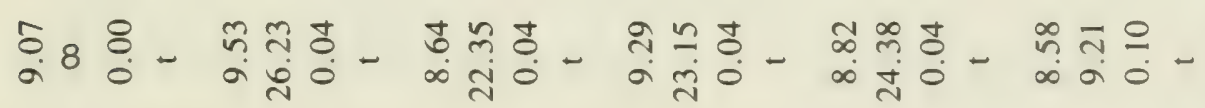

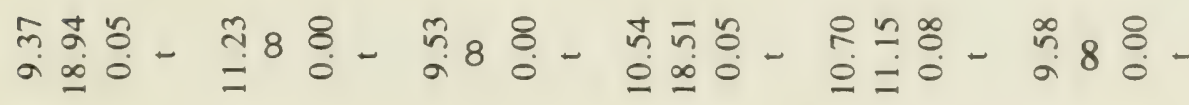

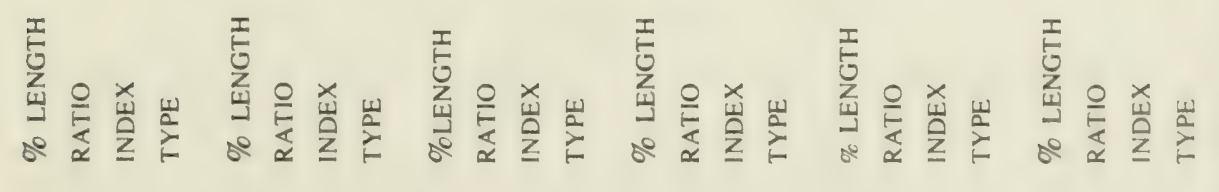

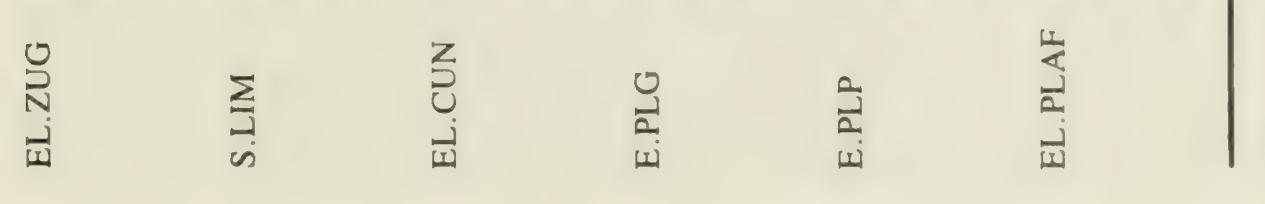




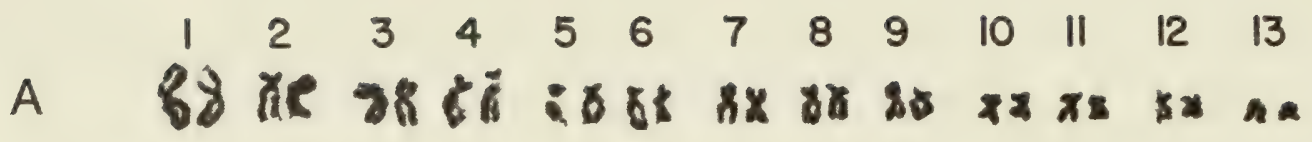

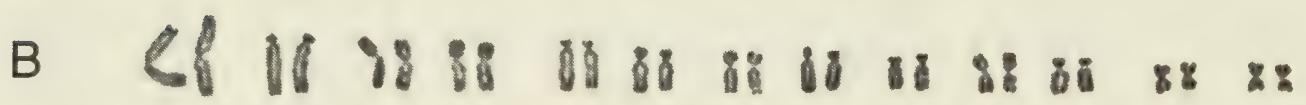

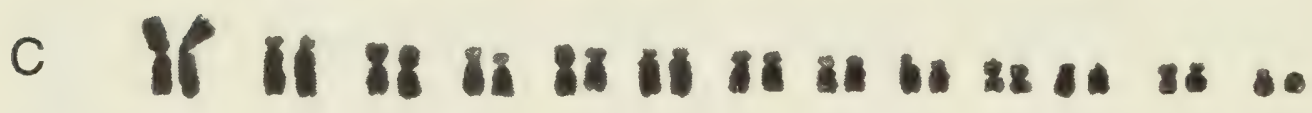

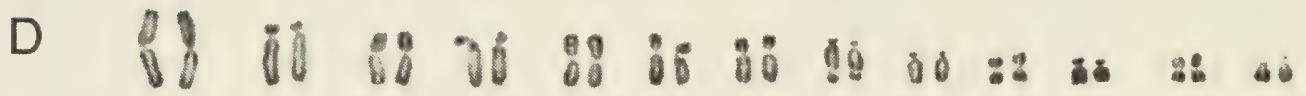

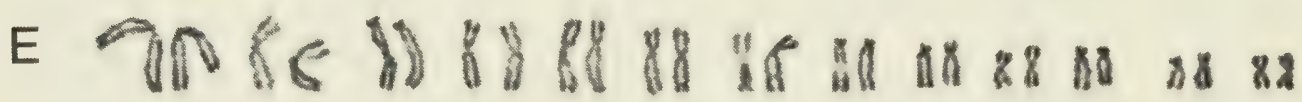

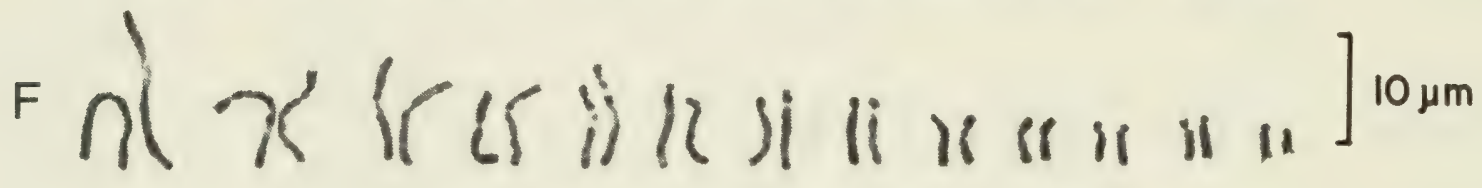

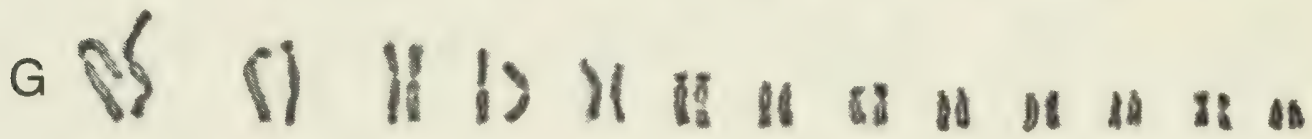

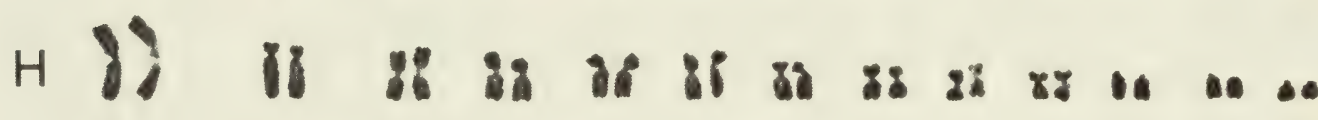

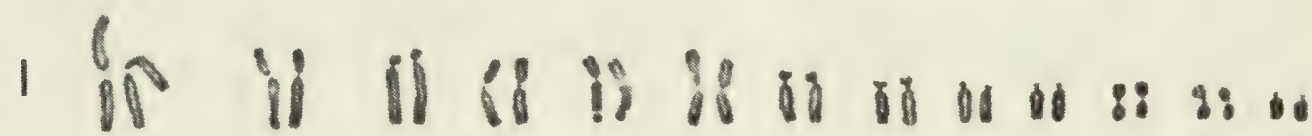

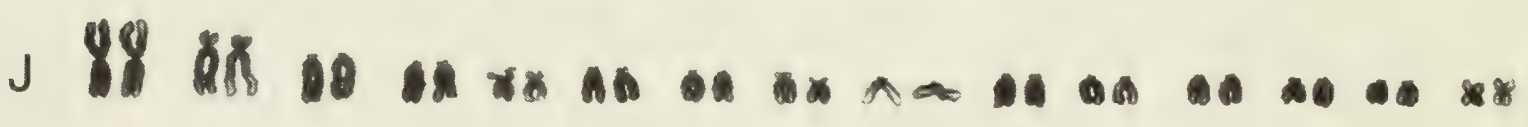

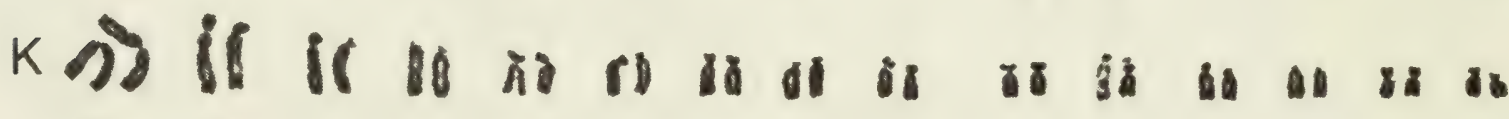
L

Fig. 6. Karyotypes of Puerto Rican species of Eleutherodactylus presented in the same order as the idiograms (Figs. 2 and 3): E. wightmanae (A), E. eneidae (B), E. cooki (C), E. coqui (D), E. locustus (E), E.gryllus (F), E. brittoni (G), E. hedricki (H), E. antillensis (I), E. karlschmidti (J), $E$. richmondi $(\mathrm{K})$, and $E$. unicolor $(\mathrm{L})$. The scale at the right is the same for all the karyotypes except $E$. unicolor (L) which was printed at one-half the size of the other karyotypes and the scale represents $20 \mu \mathrm{m}$ for $E$. unicolor.

chromosomes (Darlington, 1939; Muller, 1938; White, 1954, 1973). This has, perhaps, led to the generalization that basic or primitive karyotypes have more chromosomes and more telocentric chromosomes than the advanced karyotypes (Dingerkus, 1979; Matthey, 1945, 1949; Morescalchi, 1968, 1973). Muller (1938) and White (1954) maintain that chromosome fission through the splitting of a centromere does not occur, but this opinion is contested by Southern (1969) and John and Freeman (1975). Recently, with the aid of banding techniques (Hsu et al., 1975; 
Ohno, 1974) and electron microscopy (Moens, 1978), Holmquist and Dancis (1979) have proposed models which relate to the latency of centromeres, dicentric chromosomes, and telomere associations of chromosomes. The models suggest that centromeres may be gained and that telomeres may function as centromeres following a chromosome fission.

It is obvious that karyotypic evolution by centric fusions and fissions or dissociations is widespread in Eleutherodactylus. It is also evident that translocations and inversions must have taken place to account for the observed variations among species that have the same number of chromosomes or chromosome arms. Simply counting the number of chromosome arms would not sufficiently explain karyotypic evolution in this genus. Eleutherodactylus should prove to be an ideal genus for studying chromosome restructuring.

\section{Significance of Chromosome Variation}

Anurans have generally been assumed to be karyotypically stable vertebrates (White, 1974; Wilson et al., 1974). Eleutherodactylus provides an obvious exception to this generalization but there are other exceptions. An apparent correlation exists between chromosome variability and terrestriality, which involves parental behaviour, territoriality, and small clutch size (Bogart, 1974, in press). Inbreeding and territorality in anurans may facilitate chromosome alterations which may become fixed in insolated populations (Bogart, in press). The absolute amount of genetic variation between populations of Eleutherodactylus has not been assessed, but increased chromosome numbers through the production of telocentric chromosomes or polyploidy (Bogart, 1980) would increase the number of linkage groups and provide the opportunity for greater variation through assortment. Also, fewer genes can be close to the centromere in telocentric chromosomes, a situation that would increase the chances for a larger number of genes to be involved in cross-over events if they occur. The selective advantage of increased genetic variation is assumed to be important for subsequent speciation or for species survival (Dobzhansky et al., 1977), but the predictability of a species' projected survival or later speciation must remain hypothetical.

The environmental variation in the Greater Antilles with respect to elevation and moisture is extreme and there is ample opportunity for environmental partitioning and subsequent isolation. There is also the possibility of reduced competition for certain resources because many potential competitors did not gain access to the various islands. In addition to the 131 West Indian species of Eleutherodactylus (Schwartz and Thomas, 1975), geographically variant populations and subspecies are recognized (Lynch, 1967; Schwartz, 1970, 1974, 1976; Schwartz and Thomas, 1975). Such seemingly rapid speciation of Eleutherodactylus as has occurred in the Antilles has not been found in most other anuran genera.

\section{Evolutionary Considerations}

The use of chromosomal similarities and differences for evolutionary studies relies on the ability to understand how karyotypes evolve over time in order to establish certain types of chromosomal mutational events. From studies of other anuran groups, it has 


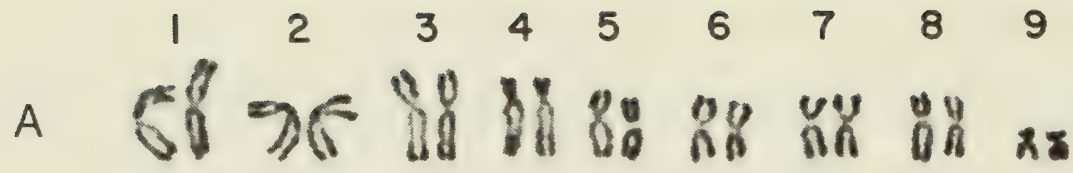

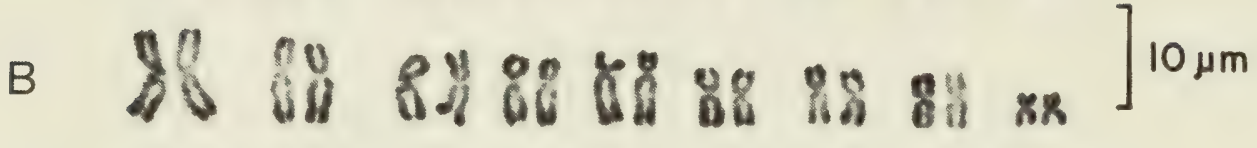
C मै पी

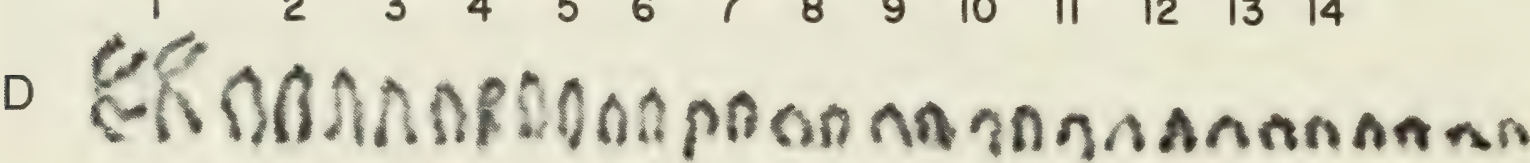 $\begin{array}{lllllllllllllll}1 & 2 & 3 & 4 & 5 & 6 & 7 & 8 & 9 & 10 & 11 & 12 & 13 & 14 & 15\end{array}$

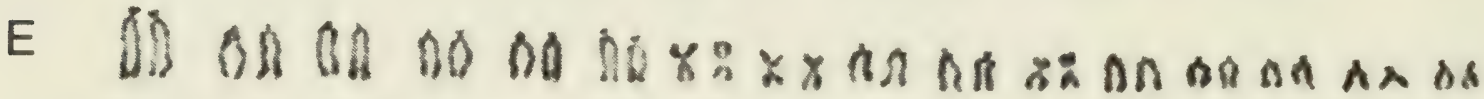

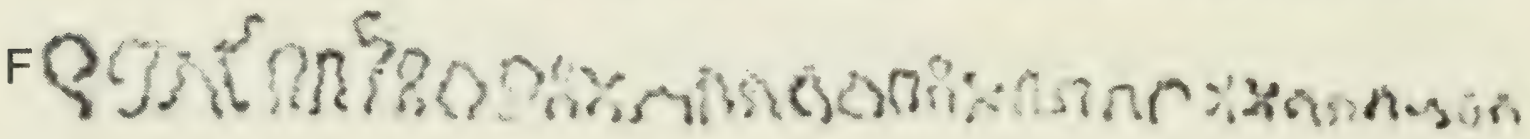

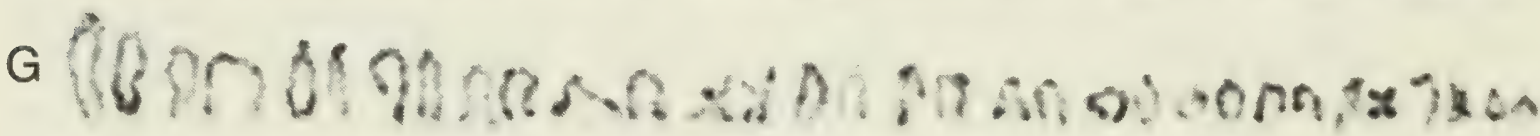

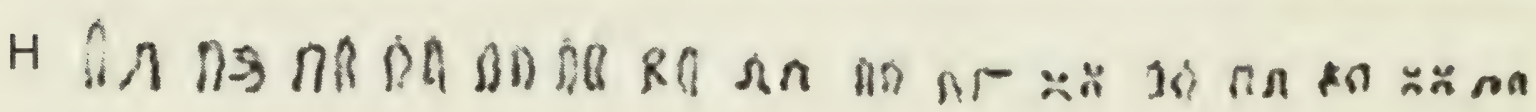

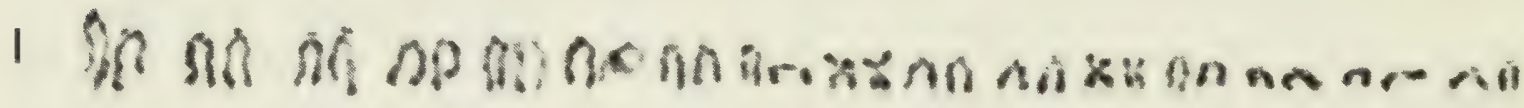

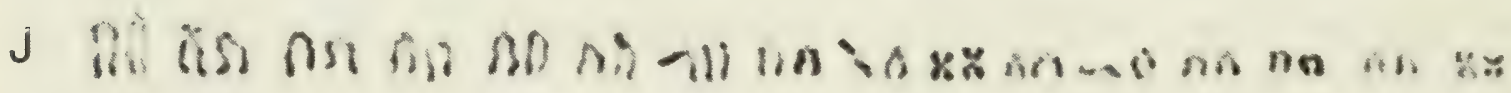

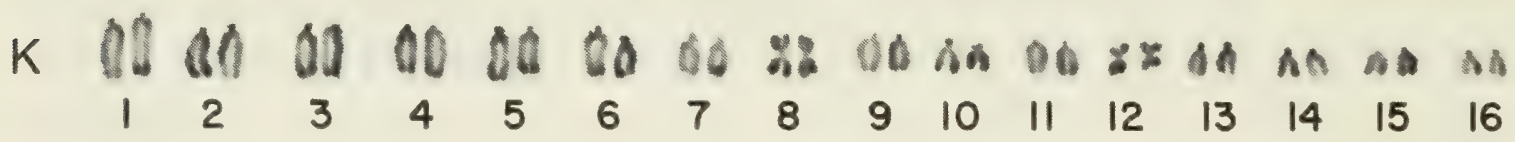

Fig. 7. Karyotypes of Cuban Eleutherodactylus species and Sminthillus limbatus. The karyotypes are presented in the same order as the idiograms (Figs. 4 and 5): E. auriculatus (A), E. varians (B), E. atkinsi (C), E. dimidiatus (D), E. klinikowskii (E), E. zugi (F), Sminthillus limbatus (G), E. cuneatus (H), E. planirostris goini (I), E. p. planirostris from Havana, Cuba (J), and E. p. planirostris from Tampa, Florida $(\mathrm{K})$. The scale is the same for all the karyotypes.

been assumed that karyotypic evolution is slow (Wilson et al., 1974) and that small differences are important. Eleutherodactylus may provide some answers concerning mechanisms of chromosomal evolution since this genus apparently has a rapid rate of chromosomal evolution.

Representatives of $E$. planirostris from three localities demonstrated chromosomal differences (Fig. 7) which may be related to a number of small translocations and inversions. Altering the number of chromosomes appears to be a more profound genetic event than altering sizes or ratios and should require a longer time to achieve. If so, the two 18-chromosome species of the auriculatus group are more closely related to 18-chromosome species in Costa Rica than they are to the other groups on 


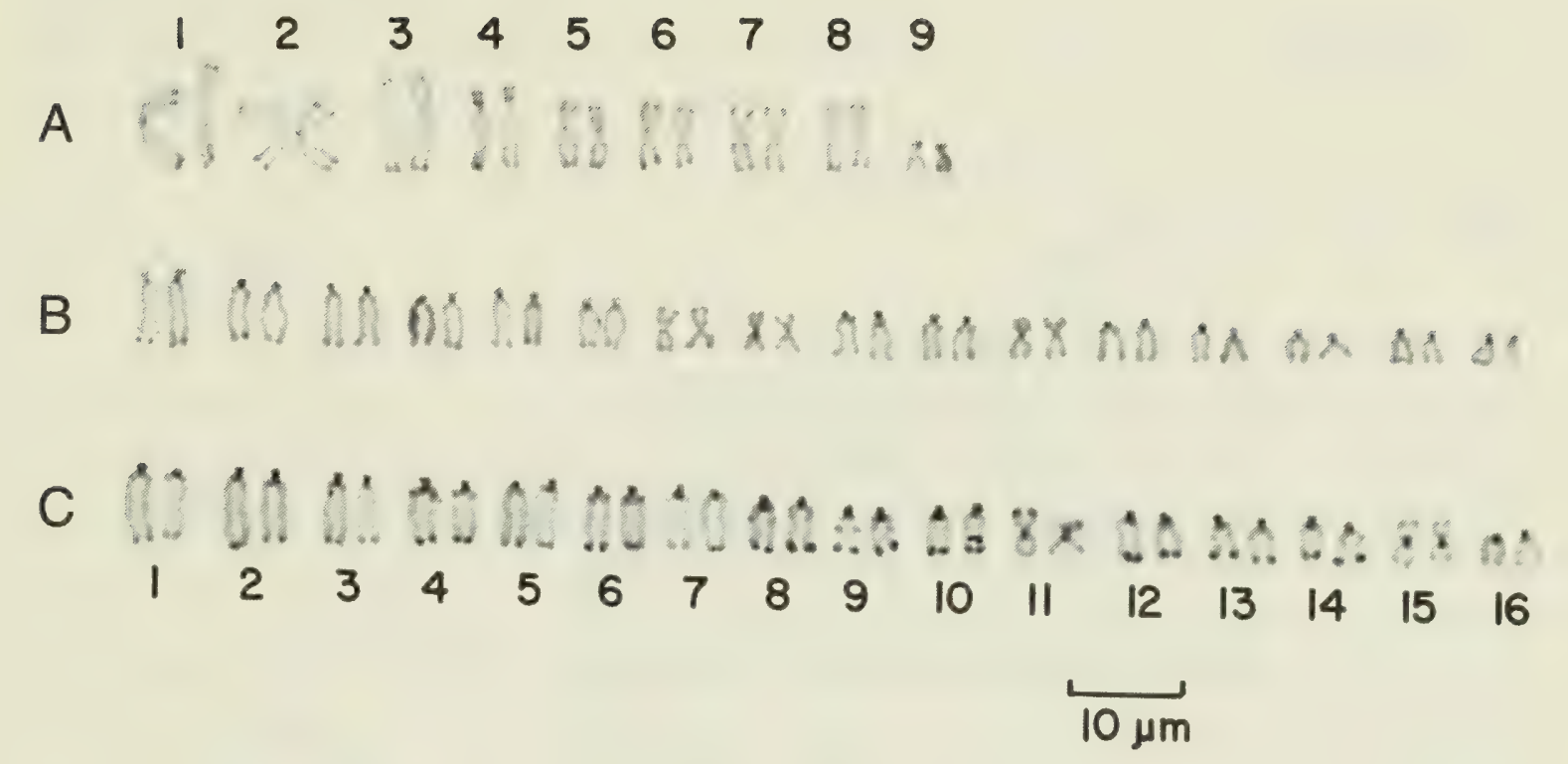

Fig. 8. C-banded karyotypes of Eleutherodactylus auriculatus (A), E. klinikowskii (B), and E. cuneatus (C). The scale is the same for all three karyotypes.

the Antilles with elevated numbers of chromosomes. The 32-chromosome ricordi group members possibly relate to an ancestral species which arrived on Cuba independent of the arrival of an 18-chromosome species. Other ricordi and auriculatus group members are to be found in Hispaniola and Jamaica (Schwartz, 1969) and it will be interesting to examine and compare the chromosomes of these species with those of the Cuban species. Sminthillus limbatus is restricted to Cuba and is possibly the result of an early dichotomy on Cuba from a species of the ricordi group. Some Puerto Rican species, and the Cuban E. dimidiatus, have 30 chromosomes. It is possible that an ancestral 30-chromosome group was widespread through the Antilles. E. atkinsi is the only 28-chromosome species of eleutherodactyline frog that has been found and if this species is related to the ricordi group as suggested by Dunn (1926), the number change could have occurred in Cuba. Centric dissociation of chromosomes 1 and 2 in $E$. atkinsi would produce a 32-chromosome karyotype similar to those of $E$. cuneatus or Sminthillus limbatus. It is likely that $E$. atkinsi's ancestral karyotype consisted of 32 chromosomes and that chromosomes 1 and 2 are the result of centric fusions.

The 26-chromosome Puerto Rican species are chromosomally similar to each other and could be related to a common 26-chromosome ancestor. The only other 26-chromosome eleutherodactyline species which has been encountered is Syrrhophus leprus from Vera Cruz State in Mexico (Bogart, 1973b). Although generically distinct, Syrrhophus has been included by Lynch $(1971,1976)$ with the Antillean Eleutherodactylus in his Alpha division and is, therefore, more closely aligned with Antillean Eleutherodactylus than it is with Beta division Eleutherodactylus in Mexico, Central America, and South America. Other than 30-chromosome Cuban and Puerto Rican Eleutherodactylus, the only other species that has been found to have this chromosome number in this same complex is Syrrhophus marnockii (Bogart, 1973b), which is also in Lynch's Alpha division.

Based on the relatively limited chromosomal information obtained, it would appear that the Antillean Eleutherodactylus are derived from at least four distinct groups involving 18-, 26-, 30-, and 32-chromosome ancestors, which have representatives on the mainland. Subsequent speciation, involving chromosomal changes, has taken 


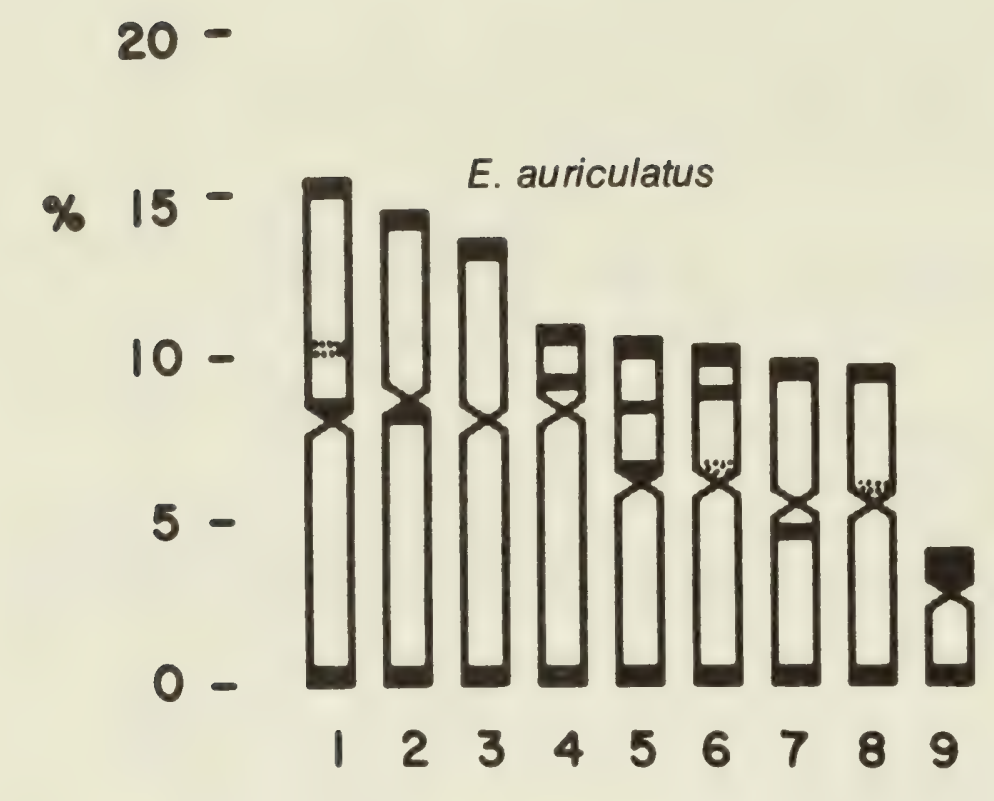

$20-$

$\% 15-$

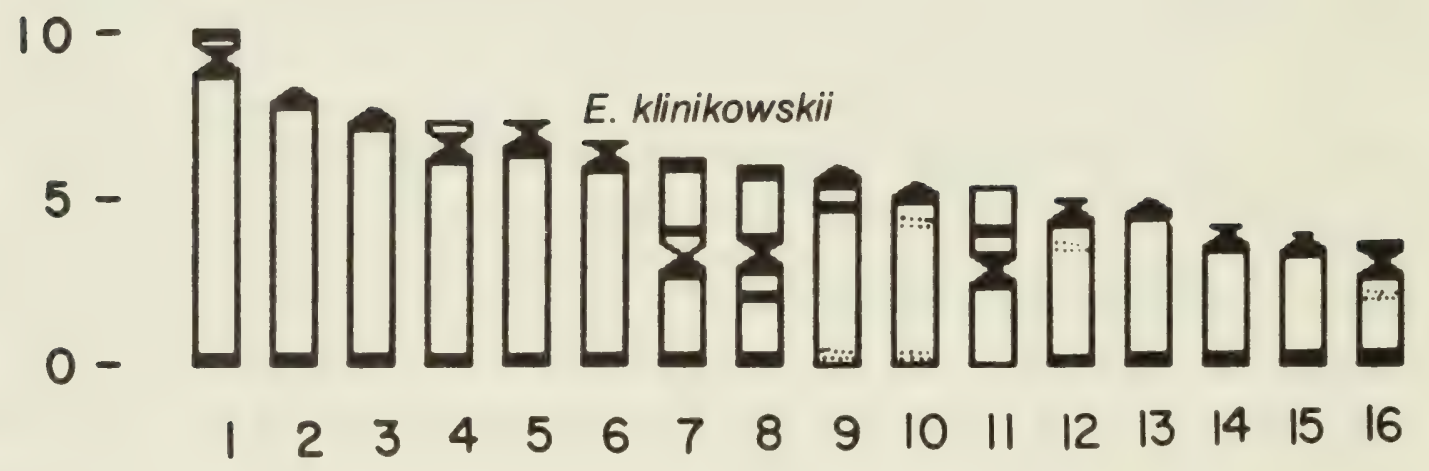

$20-$

$\% 15-$

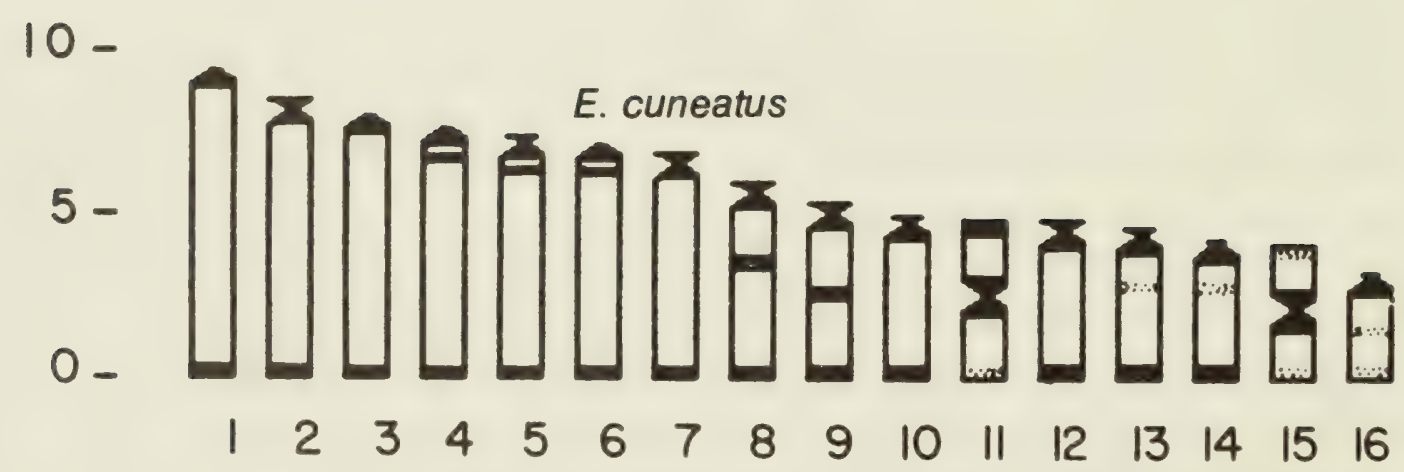

Fig. 9. Idiograms used to interpret the C-bands that were resolved in three species of Eleutherodactylus (Fig. 8). Densely stained constitutive heterochromatin regions are black and weakly staining regions are dotted. Compare the idiograms in this figure with those in Figs. 4 and 5. 
place in Cuba and Puerto Rico. Other groups and the possible directions of invasions may eventually be appreciated when additional species have been examined from Cuba, Haiti, and Jamaica.

\section{Conclusion}

Even though 21 species of Antillean eleutherodactyline species were examined, this sample represents a small percentage of the West Indian species. At best, conclusions based on the available evidence are preliminary and await confirmation when many more species have been karyotypically examined. Compared with most other anuran genera, Eleutherodactylus species appear to demonstrate rapid chromosomal evolution which involved alterations in chromosome number, pericentric inversions, and translocations. Increased numbers of centromeres and chromosomes must have arisen within the genus Eleutherodactylus. The few C-banded chromosome preparations demonstrate strongly staining telomeres and large amounts of constitutive heterochromatin. The $\mathrm{C}$-band variation means that this technique will probably be useful for subsequent chromosomal analyses in Eleutherodactylus, as it has been for other anurans (Schmid, 1978a, 1978b; Veloso and Iturra, 1979). Sminthillus limbatus is karyotypically more similar to Cuban ricordi group species than to auriculatus or dimidiatus group species. This chromosomal information, as well as previous morphological comparisons (Griffiths, 1959; Heyer, 1975; Lynch, 1971), would justify the inclusion of $S$. limbatus in the genus Eleutherodactylus. Some species on the mainland have the same chromosome numbers and karyotypes similar to Antillean groupings. Some 30-chromosome species are found on both Puerto Rico and Cuba. Most of the number changes among the eleutherodactyline species appear to predate the isolation of island fauna, but speciation of $E$. atkinsi may have coincided with a chromosome number reduction in Cuba. In most instances, the chromosomal groupings correspond to groupings formulated using morphological characters.

\section{Acknowledgements}

I wish to thank Dr. George Drewry and Dr. William F. Martin for providing the Puerto Rican specimens. As well as identifying the specimens from Puerto Rico, Dr. Drewry provided karyotypes from two species for which I did not obtain adequate results and gave me an appreciation for the diversity of Eleutherodactylus in Puerto Rico. I deeply appreciate the friendship and help extended to me by my Cuban associates who turned what otherwise would have been a futile and frustrating collecting trip to Cuba into a pleasant and rewarding experience. I also thank Albert Schwartz who confirmed the identifications of the Cuban species and David Green whose wonderful computer programs saved so much time. I thank Dr. Margaret Stewart and two anonymous reviewers who made many helpful suggestions. In addition, I thank my understanding wife, Jo Ellen, who encouraged me to use my Christmas break to collect in Cuba. This study was supported in part by the Natural Sciences and Engineering Research Council of Canada, Grant A9866. 


\title{
Literature Cited
}

\author{
ARDILA-ROBAYO. M.C. \\ 1979 Status sistematico del genero Geobatrachus Ruthven 1915 (Amphibia: Anura). Caldasia \\ $12: 383-495$ \\ BARBOUR, T. and G.K. NOBLE \\ 1920 Some amphibians from northwestern Peru, with a revision of the genera Phyllobates and \\ Telmatobius. Bulletin of the Museum of Comparative Zoology 63:393-427.
}

BOGART, J.P.

1968 Chromosome number difference in the amphibian genus Bufo: the Bufo regularis species group. Evolution 22:42-45.

1970 Los cromosomas de anfibios anuros del genero Eleutherodactylus. Actas IV Congresso Latinoamericano de Zoologia 1:65-78.

1973a Method for obtaining chromosomes. Caldasia 11:29-40.

1973b Evolution of anuran karyotypes. In Vial, J.L., ed., Evolutionary biology of the anurans. Columbia, University of Missouri Press, pp. 337-349.

1974 A karyosystematic study of frogs in the genus Leptodactylus (Anura: Leptodactylidae). Copeia 1974:728-737.

1980 Evolutionary implications of polyploidy in amphibians and reptiles. In Lewis, W.H., ed., Polyploidy: biological relevance. New York, Plenum Press, pp. 341-378.

In press How many times has terrestrial breeding evolved in anuran amphibians? Monitore Zoologico Italiano.

COCHRAN, D.M. and C.J. GOIN

1970 Frogs of Colombia. Bulletin of the United States National Museum 288:1-655.

DANIEL, A. and LAM-PO-TAN, P.R.L.C.

1976 Structure and inheritance of some heterozygous Robertsonian translocations in man. Journal of Medical Genetics 13:381-388.

DARLINGTON, C.D.

1939 Misdivision and the genetics of the centromere. Journal of Genetics 37:341-364.

DINGERKUS, G

1979 Chordate cytogenetic studies: an analysis of their phylogenetic implications with particular reference to fishes and the living coelacanth. California Academy of Sciences Occasional Papers 134:111-127.

DOBZHANSKY, T., F. AYALA, G.L. STEBBINS, and J.W. VALENTINE

1977 Evolution. San Francisco, W.H. Freeman. 572 pp.

DUNN. E.R.

1926 Additional frogs from Cuba. Occasional Papers of the Boston Society of Natural History 5:209-215.

GOIN, C.J.

1947 Studies on the life history of Eleutherodactylus ricordii planirostris (Cope) in Florida with special reference to the local distribution of an allomorphic color pattern. Gainsville, University of Florida Press. 66 pp.

1954 Remarks on the evolution of color pattern in the gossei group of the frog genus Eleutherodactylus. Annals of the Carnegie Museum 33:185-195.

GORMAN, G.C.

1973 The chromosomes of the Reptilia. In Chiarelli, A.B. and E. Capanna, eds., Cytotaxonomy and vertebrate evolution. London, Academic Press, pp. 349-424. 
GREEN, D.M., J.P. BOGART, E.H. ANTHONY, and D.L. GENNER

1980 An interactive, microcomputer-based karyotype analysis system for phylogenetic cytotaxonomy. Computers in Biology and Medicine 10: 219-227.

GRIFFITHS, I.

1959 The phylogeny of Sminthillus limbatus and the status of the Brachycephalidae (Amphibia, Salientia). Proceedings of the Zoological Society of London 132:457-489.

HEYER, W.R

1975 A preliminary analysis of the intergeneric relationships of the frogs in the family Leptodactylidae. Smithsonian Contributions to Zoology 199:1-55.

HSU, T.C., S. PATHAK, and T.R. CHEN

1975 The possibility of latent centromeres and a proposed nomenclature system for the total chromosome and whole arm translocations. Cytogenetics and Cell Genetics 15:41-49.

HOLMQUIST, G.P. and B. DANCIS

1979 Telomere replication, kinetochore organizers, and satellite DNA evolution. Proceedings of the National Academy of Sciences (U.S.A.) 76:4566-4570.

JOHN, B. and M. FREEMAN

1975 Causes and consequences of Robertsonian exchange. Chromosoma 52:123-136.

LYNCH, J.D.

1967 Synonomy, distribution and variation in Eleutherodactylus decoratus of Mexico (Amphibia: Leptodactylidae). Transactions of the Illinois State Academy of Science 60:299-304.

1971 Evolutionary relationships, osteology, and zoogeography of leptodactyloid frogs. University of Kansas Museum of Natural History, Miscellaneous Publication 53:1-238.

1976 The species groups of the South American frogs of the genus Eleutherodactylus (Leptodactylidae). Occasional Papers of the Museum of Natural History, University of Kansas, 61:1-24.

LYNCH, J.D. and W.E. DUELLMAN

1980 The Eleutherodactylus of the Amazonian slopes of the Ecuadorian Andes (Anura: Leptodactylidae). University of Kansas Museum of Natural History, Miscellaneous Publication 69:1-86.

MATTHEY, R

1945 L'évolution de la formule chromosomiale chez les vertébrés. Experientia 1:50-56, 78-86.

1949 Les chromosomes des vertébrés. Lausanne, Rouge. 356 pp.

1973 The chromosome formulae of eutherian mammals. In Chiarelli, A.B. and E. Capanna, eds., Cytotaxonomy and vertebrate evolution. London, Academic Press, pp. 531-616.

MOENS, P.B

1978 Kinetochores of grasshoppers with Robertsonian chromosome fusions. Chromosoma $67: 41-54$.

MORESCALCHI, A

1968 Hypotheses on the phylogeny of the Salientia based on karyological data. Experientia 24:964-966.

1973 Amphibia. In Chiarelli, A.B. and E. Capanna, eds., Cytotaxonomy and vertebrate evolution. London, Academic Press, pp. 233-348.

MULLER, H.J

1938 The re-making of chromosomes. Collecting Net, Woods Hole, 13:181-195, 198. (Reprinted in Studies in Genetics, the selected papers of H.J. Muller. Bloomington, Indiana University Press, 1962).

NOBLE, G.K

1931 The biology of the Amphibia. New York, McGraw-Hill. 577 pp. 
1974 Conservation of ancient linkage groups in evolution and some insight into the genetic regulatory mechanism of X-inactivation. Cold Spring Harbor Symposium on Quantitative Biology 38:155-164.

PATTON, J.L.

1967 Chromosome studies of certain pocket mice, genus Perognathus (Rodentia: Heteromyidae). Journal of Mammalogy 48:27-37.

RIVERO, J.A.

1978 The amphibians and reptiles of Puerto Rico. San Juan, Editorial Universitaria, Universidad de Puerto Rico. 152 pp.

ROBERTSON, W.R.B

1916 Chromosome studies. I. Taxonomic relationships shown in the chromosomes of Tettigidae and Acrididae. V-shaped chromosomes and their significance in Acrididae, Locustidae and Gryllidae: chromosomes and variation. Journal of Morphology 27:179-331.

SCHMID, M

1978a Chromosome banding in Amphibia. I. Constitutive heterochromatin and nucleolus organizer regions in Bufo and Hyla. Chromosoma 66:361-388.

1978b Chromosome banding in Amphibia. II. Constitutive heterochromatin and nucleolus organizer regions in Ranidae, Microhylidae and Rhacophoridae. Chromosoma 68:131148 .

SCHWARTZ, A.

1969 The Antillean Eleutherodactylus of the auriculatus group. Studies of the Fauna of Curacao and other Caribbean Islands 30:99-115.

1970 The subspecies of Eleutherodactylus schmidti Noble (Anura: Leptodactylidae). Caribbean Journal of Science 10:109-118.

1973 Six new species of Eleutherodactylus (Anura, Leptodactylidae) from Hispaniola. Journal of Herpetology 7:249-273.

1974 Eleutherodactylus planirostris (Cope). Catalogue of American Amphibians and Reptiles 154.1-154.4. Lawrence, American Society of Ichthyologists and Herpetologists.

1976 Two new species of Hispaniolan Eleutherodactylus (Anura, Leptodactylidae). Herpetologica $32: 163-171$.

SCHWARTZ, A. and R. THOMAS

1975 A check-list of West Indian amphibians and reptiles. Carnegie Museum of Natural History, Special Publication 1:1-216.

SOUTHERN, D.I

1969 Stable telocentric chromosomes produced by centric misdivision in Myrmeleotettix maculatus (Thunb). Chromosoma 26:140-147.

SUMNER, A.T

1972 A simple technique for demonstrating centromeric heterochromatin. Experimental Cell Research 75:304-306.

VELOSO, M.A. and P. ITURRA

1979 Posibilidades del analisis citogenético en un estudio de bandeo cromosómico en dos especies de anfibios (Anura-Leptodactylidae). Archives Biologia Medecina Experimentale 12:91-96

WHITE, M.J.D.

1954 Animal cytology and evolution. 2nd ed. Cambridge, Cambridge University Press. $454 \mathrm{pp}$.

1973 Animal cytology and evolution. 3rd ed. Cambridge, Cambridge University Press. 961 pp.

WILSON, A.C., V.M. SARICH, and L.R. MAXSON

1974 The importance of gene rearrangements in evolution: evidence from studies on rates of chromosomal, protein and anatomical evolution. Proceedings of the National Academy of Sciences (U.S.A.) 71:3028-3030 

ISBN 0-88854-280-1 